\title{
Eunotia (Bacillariophyceae) from a subtropical stream adjacent to Iguaçu National Park, Brazil, with the proposition of a new species
}

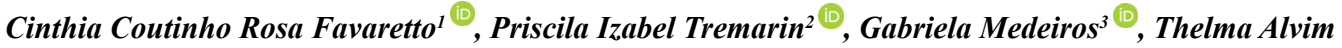 \\ Veiga Ludwig ${ }^{\circledR 0} *$ \& Norma Catarina Bueno ${ }^{(1)}$ \\ ${ }^{1}$ Universidade Estadual do Oeste do Paraná, Programa de Pós-Graduação em Conservação e Manejo de \\ Recursos Naturais, Cascavel, PR, Brasil. \\ ${ }^{2}$ Acqua Diagnósticos Ambientais Ltda., Rua Lourenço Volpi, 82640-440, Curitiba, PR, Brasil. \\ ${ }^{3}$ Universidade Estadual do Oeste do Paraná, Programa de Pós-Graduação em Engenharia Agrícola, \\ Cascavel, PR, Brasil. \\ ${ }^{4}$ Universidade Federal do Paraná, Departamento de Botânica, Curitiba, PR, Brasil. \\ *Corresponding author:Thelma Alvim Veiga Ludwig,e-mail:veiga13ufpr@gmail.com
}

FAVARETTO, C.C.R., TREMARIN, P.I., MEDEIROS, G., LUDWIG, T.A.V., BUENO, N.C. Eunotia (Bacillariophyceae) from a subtropical stream adjacent to Iguaçu National Park, Brazil, with the proposition of a new species. 21(1): e20190811. https://doi.org/10.1590/1676-0611-BN-2019-0811

\begin{abstract}
Eunotia species from a stream located in the surrounding area of the Iguaçu National Park conservation unit were analyzed. Samples were monthly collected from September 2012 to August 2013. The periphytic material, manually obtained by squeezing aquatic macrophytes, was oxidized and analyzed under light and scanning electron microscopy. Twenty-one infrageneric taxa of Eunotia were identified, measured, and illustrated. Eunotia caniculoides sp. nov. is proposed as a new species, and eight taxa are new records for Paraná state.
\end{abstract}

Keywords: Bacillariophyta; diatoms; periphyton; southern Brazil; taxonomy.

\section{Eunotia (Bacillariophyceae) de um riacho subtropical adjacente ao Parque Nacional do Iguaçu, Brasil, com a proposta de uma espécie nova}

Resumo: Espécies de Eunotia Ehrenberg de um ambiente lótico localizado em área adjacente à unidade de conservação Parque Nacional do Iguaçu foram analisadas. As coletas foram realizadas mensalmente de setembro de 2012 a agosto de 2013. O material perifítico obtido do espremido manual de macrófitas aquáticas foi oxidado e analisado sob microscopia óptica e eletrônica de varredura. Vinte e um táxons de Eunotia foram identificados, medidos e ilustrados. Eunotia caniculoides sp. nov. é proposta como uma nova espécie e oito táxons constituem novos registros para o estado do Paraná.

Palavras-chave: Bacillariophyta; diatomáceas; perifiton; sul do Brasil; taxonomia. 


\section{Introduction}

The genus Eunotia Ehrenberg is characterized by the valve isopolarity, apical axis asymmetry, uniseriate striae, short raphe system, usually restricted to the valve apices and the presence of rimoportulae (Kociolek \& Spaulding 2003, Furey 2011). The extant species are found in freshwater environments (Round et al. 1990) but some fossil Eunotia have already been described from marine sediments in New Zealand (Novitski \& Kociolek 2005). The genus includes species with ecological optimum in the epiphyton and metaphyton of dystrophic to oligotrophic waters, being valuable indicators of acidic and lowconductivity conditions (Round et al. 1990, Van Dam et al. 1994, Cantonati \& Lange-Bertalot, 2011, Cox 2015).

Eunotia is one of the most common and species-rich diatom genera in the Neotropics (Patrick 1940a, 1940b, Hustedt 1952a, 1952b, 1965, Metzeltin \& Lange-Bertalot 1998, 2007, Sala et al. 2002a, 2002b, Dunck et al 2016, Faustino et al. 2016, Costa et al. 2017), with remarkable diversity in Brazilian acidic environments (Ferrari et al. 2007, Bicca et al. 2011, Canani \& Torgan 2013, Dunck et al. 2013a, 2013b, 2016, Cavalcante et al. 2014). In the state of Paraná, the genus were reported by Ludwig \& Valente-Moreira (1989), Fürstenberger \& Valente-Moreira (2000), Tremarin et al. (2008), Faria et al. (2010), Bertolli et al. (2010), Santos et al. (2011), Bartozek et al. (2013), Marra et al. (2016), SilvaLehmkuhl et al. (2019), and Bartozek et al. (2020) recently proposed a new species. Based on a bibliographic check-list of freshwater diatom studies developed in the state of Paraná from 1954 to 2009, Tremarin et al. (2009) listed 110 Eunotia infrageneric taxa, and Cavalcante et al. (2014) mention about 245 taxa registered to Brazil.

The purpose of the present publication was to investigate the species diversity of Eunotia from a stream located in the surrounding area of the Iguaçu National Park conservation unit. A new species, Eunotia caniculoides, was formally described. The distinctive characters between similar taxa were discussed and taxonomical notes were provided. Distribution in the state of Paraná and ecological informations were also added.

\section{Material and Methods}

The present study was carried out on the Tenente João Gualberto stream, located in a conservation unit area adjacent to the Iguaçu National Park, in the municipality of São Miguel of Iguaçu (2528'36.3'S; 54 $\left.19^{\prime} 40.9^{\prime \prime} \mathrm{W}\right)$, the western region of the state of Paraná. According to Horton-Strahler criteria (Horton 1945, Strahler 1952), the stream is a major tributary of the Baixo Iguaçu Basin, having its source and part of its course among agricultural fields (Figure 1). The regional climate is Cfa type, subtropical humid mesotherm, with well-defined summer and winter periods, and rains distributed during the year (Alvares et al. 2013).

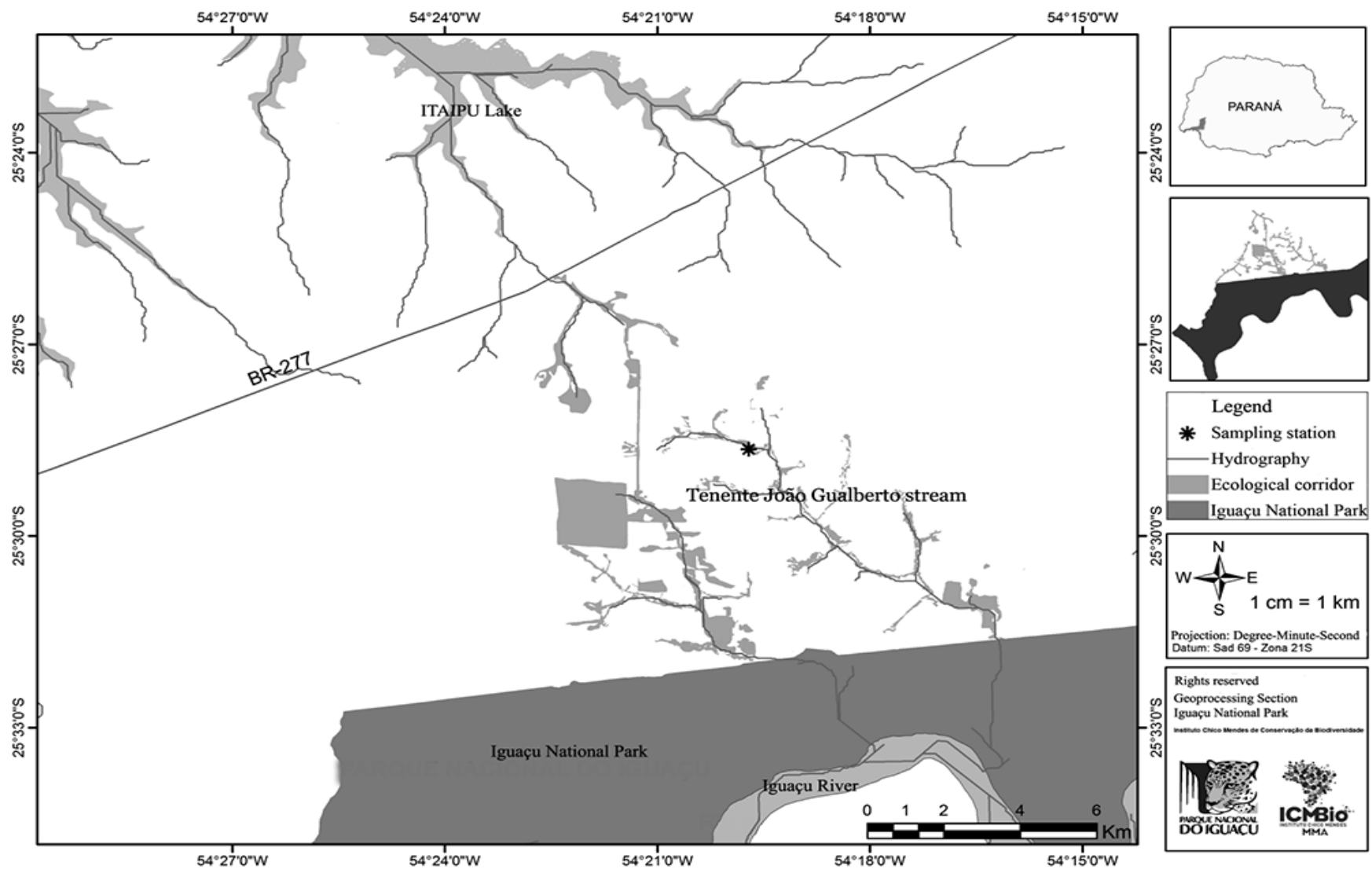

Figure 1. Location of the sampling station in the Tenente João Gualberto stream, São Miguel do Iguaçu, PR, Brazil. 
Diatom samples were collected monthly, from September 2012 to August 2013. Limnological variables as dissolved oxygen ( $\left.\mathrm{mg} \mathrm{L}^{-1}\right), \mathrm{pH}$, water temperature $\left({ }^{\circ} \mathrm{C}\right)$, conductivity $\left(\mathrm{mS} \mathrm{cm}^{-1}\right)$, and turbidity (NTU) were measured in the field using a Horiba U-5000 multiparameter probe. Nutrient analysis of organic nitrogen $-\mathrm{N}_{\text {org }} \cdot\left(\mathrm{mg} \mathrm{L}^{-1}\right)$, ammoniac nitrogen $-\mathrm{NH}_{4}^{+}\left(\mathrm{mg} \mathrm{L}^{-1}\right)$, nitrate $-\mathrm{NO}_{3}^{-}\left(\mathrm{mg} \mathrm{L}^{-1}\right)$, nitrite $-\mathrm{NO}_{2}^{-}\left(\mathrm{mg} \mathrm{L}^{-1}\right)$, orthophosphate $-\mathrm{PO}_{4}^{-3}\left(\mathrm{mg} \mathrm{L}^{-1}\right)$ e total phosphorous - $\mathrm{TP}\left(\mathrm{mg} \mathrm{L}^{-1}\right.$, were carried out at the Limnological Laboratory of the Research Group on Fishery Resources and Limnology (GERPEL), from UNIOESTE, campus Toledo, according to American Public Health Association (2005). Weekly precipitation $(\mathrm{mm})$ data were provided by Paraná Meteorological System (SIMEPAR). Minimum and maximum values of limnological data were described for each identified Eunotia species.

Periphytic samples were removed by manually squeezing the aquatic macrophyte Eleocharis minima Kunth (Cyperaceae) and were preserved in Transeau solution, in 1:1 proportion (Bicudo \& Menezes 2017). The organic matter was eliminated by oxidation with $\mathrm{KMnO}_{4}$ and $\mathrm{HCl}$ according to Simonsen (1974) technique modified by MoreiraFilho \& Valente-Moreira (1981). Cleaned material was dried onto glass coverslips and mounted on slides with Naphrax ${ }^{\circledR}(I R=1.74)$. The taxonomic analysis was performed using an Olympus BX60 light microscope equipped with a DP71 image capture camera. Subsamples from cleaned samples were mounted on aluminum stubs and coated with gold. Micrographs were taken with JEOL JSM 6360 scanning electron microscope (SEM), operated at $15 \mathrm{kV}$ and $8 \mathrm{~mm}$ working distance, housed in the Electron Microscopy Center from the Federal University of Paraná. Slides and samples were deposited in the UNOPA Herbarium, UNIOESTE, campus Cascavel and registered as shown in Table 1.

Morphological terminology follows Barber \& Haworth (1981) and Round et al. (1990). The classification system was based on Cox (2015).

Every Eunotia species was measured at the valve apical length, transapical width and striae density in the central part of the valve. The ecological information cited for identified taxa corresponds to the abiotic parameters measured in the samples collected during this study.

Constancy is a measure of species occurrence $(\mathrm{C})$ and was expressed as follows: constant $(\mathrm{C} \geq 70 \%)$, common $(30 \% \geq \mathrm{C} \leq 70 \%)$, sporadic $(10 \% \geq \mathrm{C} \leq 30 \%)$ and rare $(\mathrm{C} \leq 10 \%)($ Dajoz 2005$)$.

\section{Results}

Twenty-one taxa were measured and illustrated. Eight Eunotia taxa are new records for the state of Paraná: E. georgii Metzeltin \& Lange-Bertalot, E. karenae Metzeltin \& Lange-Bertalot, E. guianensis (Ehrenberg) De Toni, E. juettnerae Lange-Bertalot, E. pileus Ehrenberg, E. pseudosudetica var. rotundata Cavalcante, Tremarin \& T.Ludwig, E. sedina Lange-Bertalot, Bak \& Witkowski, and E. tropico-arcus Metzeltin \& Lange-Bertalot. Eunotia caniculoides sp. nov. is formally proposed as a new species and are compared with close taxa (Table 2). The occurrence of species in the samples as well as ecological and environmental data from the sampling are listed in Table 3.

Bacillariophyceae Haeckel

Eunotiophycidae D.G. Mann

Eunotiales P.C. Silva

Eunotiaceae Kützing

Eunotia Ehrenberg
Table 1. Herbarium vouchers (UNOPA), date, geographic coordinates, and collector of samples

\begin{tabular}{|c|c|c|c|}
\hline UNOPA & $\begin{array}{c}\text { Sampling } \\
\text { date }\end{array}$ & $\begin{array}{l}\text { Geographic } \\
\text { coordinates }\end{array}$ & Collector \\
\hline 3943 & 20/IX/2012 & $\begin{array}{c}25^{\circ} 28^{\prime} 36.3^{\prime \prime S} \\
54^{\circ} 19^{\prime} 40.9^{\prime \prime} \mathrm{W}\end{array}$ & Servat, L.C \\
\hline 3962 & $29 / \mathrm{X} / 2012$ & $\begin{array}{l}25^{\circ} 28^{\prime} 36.3^{\prime \prime} \mathrm{S} \\
54^{\circ} 19^{\prime} 40.9^{\prime \prime} \mathrm{W}\end{array}$ & Servat, L.C \\
\hline 3976 & $13 / \mathrm{XI} / 2012$ & $\begin{array}{l}25^{\circ} 28^{\prime} 36.3^{\prime \prime S} \\
54^{\circ} 19^{\prime} 40.9^{\prime \prime} \mathrm{W}\end{array}$ & Servat, L.C \\
\hline 4035 & 18/XII/2012 & $\begin{array}{c}25^{\circ} 28^{\prime} 36.3^{\prime \prime S} \\
54^{\circ} 19^{\prime} 40.9^{\prime \prime} \mathrm{W}\end{array}$ & Servat, L.C \\
\hline 4044 & $15 / \mathrm{I} / 2013$ & $\begin{array}{l}25^{\circ} 28^{\prime} 36.3^{\prime \prime S} \\
54^{\circ} 19^{\prime} 40.9^{\prime \prime} \mathrm{W}\end{array}$ & Servat, L.C \\
\hline 4057 & 06/II/2013 & $\begin{array}{l}25^{\circ} 28^{\prime} 36.3^{\prime \prime} \mathrm{S} \\
54^{\circ} 19^{\prime} 40.9^{\prime \prime} \mathrm{W}\end{array}$ & Servat, L.C \\
\hline 4081 & 11/III/2013 & $\begin{array}{l}25^{\circ} 28^{\prime} 36.3^{\prime \prime S} \\
54^{\circ} 19^{\prime} 40.9^{\prime \prime} \mathrm{W}\end{array}$ & Servat, L.C \\
\hline 4093 & 04/IV/2013 & $\begin{array}{c}25^{\circ} 28^{\prime} 36.3^{\prime \prime S} \\
54^{\circ} 19^{\prime} 40.9^{\prime \prime} \mathrm{W}\end{array}$ & Servat, L.C \\
\hline 4102 & $09 / \mathrm{V} / 2013$ & $\begin{array}{l}25^{\circ} 28^{\prime} 36.3^{\prime \prime S} \\
54^{\circ} 19^{\prime} 40.9^{\prime \prime} \mathrm{W}\end{array}$ & Servat, L.C \\
\hline 4116 & 06/VI/2013 & $\begin{array}{c}25^{\circ} 28^{\prime} 36.3^{\prime \prime S} \\
54^{\circ} 19^{\prime} 40.9^{\prime \prime} \mathrm{W}\end{array}$ & Servat, L.C \\
\hline 4126 & 16/VII/2013 & $\begin{array}{l}25^{\circ} 28^{\prime} 36.3^{\prime \prime S} \\
54^{\circ} 19^{\prime} 40.9^{\prime \prime} \mathrm{W}\end{array}$ & Servat, L.C \\
\hline 4136 & 12/VIII/2013 & $\begin{array}{l}25^{\circ} 28^{\prime} 36.3^{\prime \prime S} \\
54^{\circ} 19^{\prime} 40.9^{\prime \prime} \mathrm{W}\end{array}$ & Servat, L.C \\
\hline
\end{tabular}

Eunotia ambivalens Lange-Bertalot \& Tagliaventi. In: LangeBertalot (ed.), Diatoms of Europe 6, p. 49, pl. 11, figs 1-11, pl. 12, figs 1-6, pl. 13, figs. 1-11, 2011.

Figures $2 \mathrm{a}-2 \mathrm{~d}$, 4a.

Valves slightly arched, 77.6-177.3 $\mu \mathrm{m}$ long and 4.2-5.6 $\mu \mathrm{m}$ wide. Dorsal margin convex, ventral margin concave. Apices rounded. Terminal nodules near the apices. Striae parallel, $11-12$ in $10 \mu \mathrm{m}$ in the middle region of the valve. Rimoportula and areolae not visible in LM. In SEM: presence of short marginal spines, ca. 41 areolae in $10 \mu \mathrm{m}$.

Frequency of occurrence: common (Table 3 ).

Paraná State citations: cited as E. bilunaris var. linearis (Okuno) Lange-Bertalot \& Nörpel-Schempp: Tremarin et al. (2009), Faria et al. (2010), Santos et al. (2011)

Taxonomic remarks: Eunotia ambivalens distinguishes from $E$. bilunaris by slightly arched valves, almost parallel margins, ends not protracted, lower striae density $(11.5-13 / 10 \mu \mathrm{m}$ vs $13-17 / 10 \mu \mathrm{m})$, and by the presence of marginal spines (Figure 3 a) only discernible in SEM (Lange-Bertalot et al. 2011). The species "locus typicus" is Albania, Flower Lake, Lura Mountais, but it was also observed in oligotrophic alkaline or slightly acidic waters with low to moderate conductivity (Lange-Bertalot 2011).

Eunotia bilunaris (Ehrenberg) Schaarschmidt. In: Kanitz, Magyar Novenytani Lapok 5: 159, 1880.

Basionym: Synedra bilunaris Ehrenberg. Abh. Königl. Akad. Wiss. Berl. 1831: 87, 1832.

Figures $2 \mathrm{e}-2 \mathrm{j}, 4 \mathrm{~b}-\mathrm{c}$. 
Favaretto, C.C.R. et al.

Table 2. Comparison of morphometric data and morphological features of E. caniculoides sp. nov., E. canicula, E. intricans and E. sioliopsis

\begin{tabular}{|c|c|c|c|c|}
\hline Feature & E. caniculoides & E. canicula & E. intricans & E. sioliopsis \\
\hline \multirow[t]{2}{*}{ Length $(\mu \mathrm{m})$} & $30-58.5$ & $20-35^{2}$ & $17-48^{1}$ & $20-40^{4}$ \\
\hline & & $23.2-25^{3}$ & & \\
\hline Width $(\mu \mathrm{m})$ & & $3.5-5.2^{3}$ & & \\
\hline Striae in $10 \mu \mathrm{m}$ & 10-14 (center) & $14-15^{2}$ (center) & $11-13{\text { (center })^{1}}^{1}$ & $16-17{\text { (center })^{4}}^{4}$ \\
\hline $\begin{array}{l}\text { Areolar density in } \\
\text { the central area in } \\
10 \mu \mathrm{m}\end{array}$ & $38-40$ & $>35^{2}$ & $39-42^{1}$ & Up to $30^{4}$ \\
\hline Valve symmetry & $\begin{array}{l}\text { Dorsal margin slightly convex, } \\
\text { almost straight in the larger } \\
\text { valves; ventral margin straight } \\
\text { to subtly concave }\end{array}$ & $\begin{array}{l}\text { Dorsal margin convex, ventral } \\
\text { margin straight to slightly } \\
\text { concave, with valve mantle } \\
\text { thickened at the proximal } \\
\text { raphe ends }{ }^{2} \\
\text { Dorsal margin convex, ventral } \\
\text { margin concave }\end{array}$ & $\begin{array}{l}\text { Dorsal margin moderately } \\
\text { convex to almost straight in } \\
\text { the longer valves; ventral } \\
\text { margin straight or almost } \\
\text { straight }^{1}\end{array}$ & $\begin{array}{l}\text { Dorsal margin } \\
\text { convex; ventral } \\
\text { margin straight to } \\
\text { slightly concave, } \\
\text { with valve mantle } \\
\text { thickened at the } \\
\text { proximal raphe end }\end{array}$ \\
\hline Valve apices & $\begin{array}{l}\text { Apices acutely rounded, } \\
\text { nose-like, quite protracted, } \\
\text { differentiated from the main } \\
\text { body and deflected to the } \\
\text { ventral side }\end{array}$ & $\begin{array}{l}\text { Apices acutely rounded, } \\
\text { tapered, subrostrate, slightly } \\
\text { delimited by a change in the } \\
\text { slope of the dorsal margin, } \\
\text { appearing nose-like }{ }^{2}\end{array}$ & $\begin{array}{c}\text { Apices rounded, shortly } \\
\text { nose-like, not flexed to the } \\
\text { ventral side }\end{array}$ & $\begin{array}{l}\text { Apices rounded, } \\
\text { nose-like, deflected } \\
\text { to the ventral side }{ }^{4}\end{array}$ \\
\hline Rimoportula & $\begin{array}{l}\text { At one end, at the center of the } \\
\text { apex }\end{array}$ & $\begin{array}{l}\text { At one end, at the center of the } \\
\text { apex }^{2}\end{array}$ & $\begin{array}{l}\text { At one end, at the center of } \\
\text { the apex }\end{array}$ & No described \\
\hline
\end{tabular}

Lange-Bertalot \& Metzeltin (2009) $)^{1}$, Furey et al. $(2011)^{2}$, Fontana \& Bicudo (2012) ${ }^{3}$, Moser et al. $(1998)^{4}$

Valves arched tapering toward apices, 16.2-98.7 $\mu \mathrm{m}$ long and 3.1-4.6 $\mu \mathrm{m}$ wide. Dorsal margin convex, ventral margin concave sometimes with median swelling (Figure 2e-2j). Apices rounded to acutely rounded. Terminal nodules near the apices. Distal raphe end strongly curved onto the valve face. One rimoportula per valve, near the apex. Striae parallel, denser near the apices, $12-15$ in $10 \mu \mathrm{m}$ in the middle region of the valve. Areolae rounded, not visible in LM. Cingulum composed of four open bands perforated by a linear row of pores.

Frequency of occurrence: constant (Table 3).

Paraná State citations: Tremarin et al. (2009), Faria et al. (2010), Silva et al. (2010), Santos et al. (2011), Marra et al. (2016), Bartozek et al. (2013). Sometimes cited as Eunotia curvata (Kützing) Lagerstedt var. curvata and as Eunotia lunaris (Ehrenberg) Grunow var. lunaris (Tremarin et al. 2009).

Taxonomic remarks: Eunotia bilunaris is a very common periphytic species, broadly distributed in the state of Paraná, and frequently registered in Europe, Africa, Asia, North and South America (Costa et al. 2017). According to Lange-Bertalot et al. (2011), the species have a heterogeneous concept and a confusing taxonomy due to their wide morphological variability, mostly related to shape and dimensions. Specimens with uncommon morphology are common and have already been formally described as infraspecific taxa. The material analysed showed a wide morphological and metric variation of the valves, corroborating with the observations of Krammer \& Lange-Bertalot (1991) and Tavares \& Valente-Moreira (2000).
Eunotia botulitropica C.E. Wetzel \& L.F. Costa. In: Costa et al., Bibliotheca Diatomologica 64: 14, pl. 58, figs 11-46, pl. 59, figs 1-3, pl. 61, figs 1-3, 2017.

Figures $2 \mathrm{p}-2 \mathrm{t}, 4 \mathrm{~d}-4 \mathrm{f}$.

Frustule rhomboid in lateral view. Valves dorsiventral, sometimes heteropolar, 11.1-22.5 $\mu \mathrm{m}$ long and 2.5-3.7 $\mu \mathrm{m}$ wide. Dorsal margin convex, ventral margin straight to slightly concave. Apices rounded to obtusely rounded . Terminal nodules near the apices. Distal raphe end curved onto the valve face. One small rimoportula per valve, near the apex. Striae parallel, 14-19 in $10 \mu \mathrm{m}$ in the middle region of the valve. Areolae rounded, not visible in LM. Cingulum composed of four open bands perforated by one row of pores.

Frequency of occurrence: common (Table 3 ).

Paraná State citations: cited as E. intermedia (Krasske ex Hustedt) Nörpel \& Lange-Bertalot) in Tremarin et al. (2008, fig. 28).

Taxonomic remarks: Eunotia botulitropica was recently described based on samples collected in reservoirs from São Paulo state. According to Costa et al. (2017), E. botulitropica differs from E. botuliformis Wild, Nörpel \& Lange-Bertalot by its "narrower valve, lower striae density, rounded and more tapered ends" (Lange-Bertalot et al. 2011). However, the measurements and number of striae overlap, and E. botuliformis can be separated by the parallel valvar margins and the regular distribution of the striae along the valve. Eunotia botulitropica shows rhomboid girdle view, resembling E. rhomboidea Hustedt, but the latter is clearly a heteropolar species and presents larger valves (Costa et al. 2017).

Eunotia caniculoides Favaretto, Tremarin, T.Ludwig \& Bueno sp. nov. 
Table 3. Occurrence of Eunotia species, ecological data and environmental data by sampling in Tenente João Gualberto stream, Paraná, Brazil

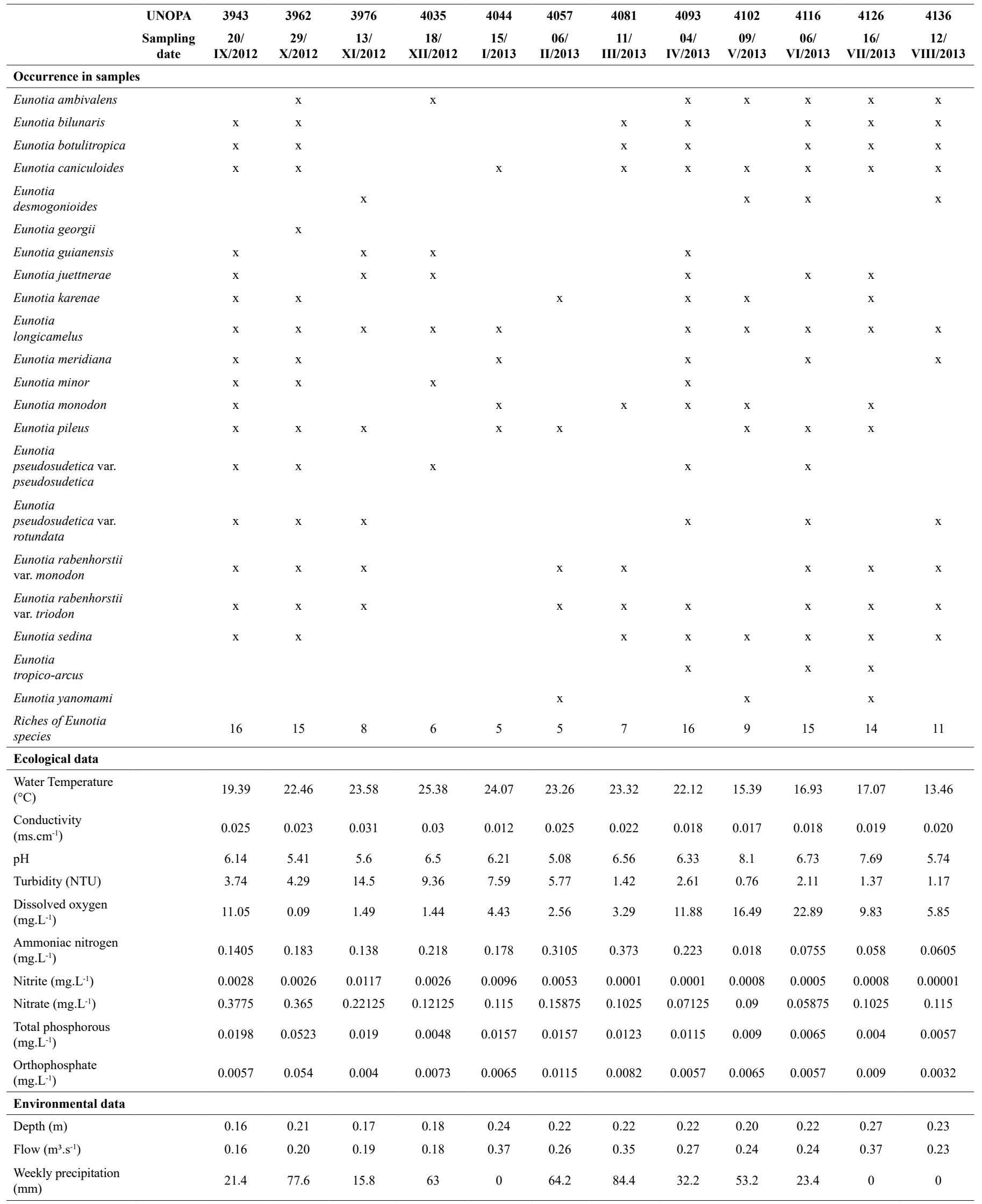




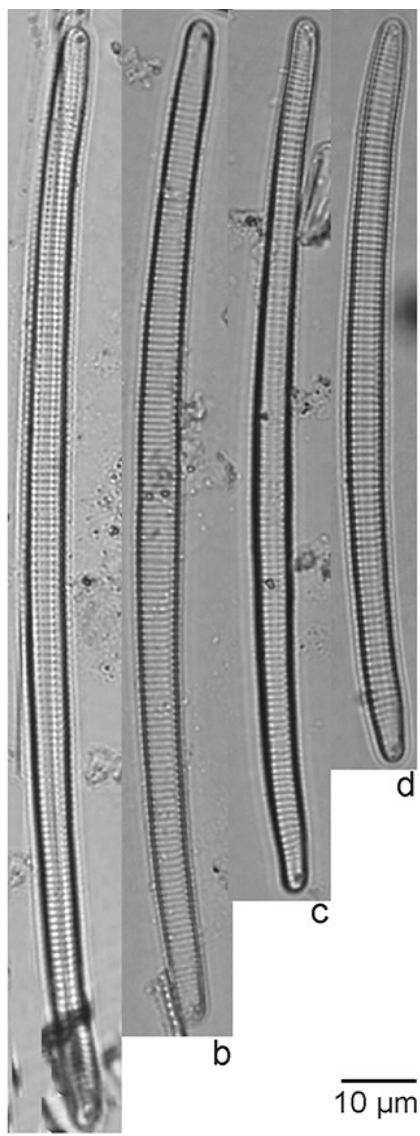

a

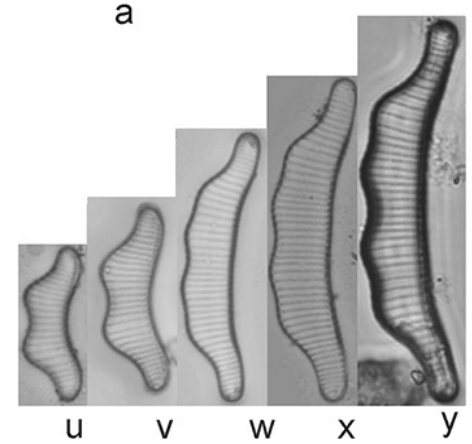

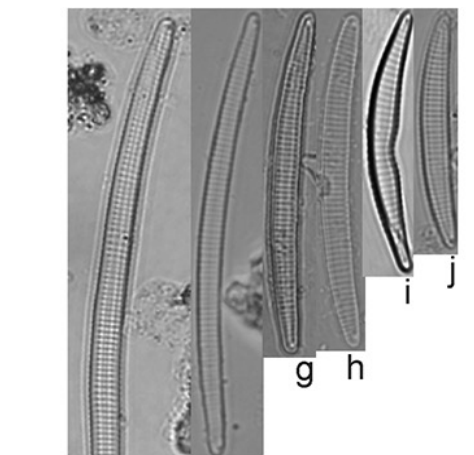
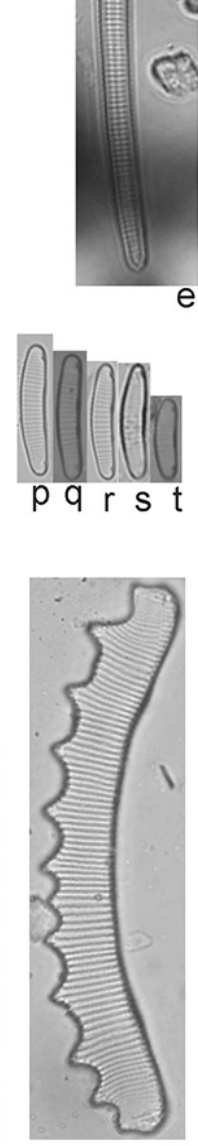

Z

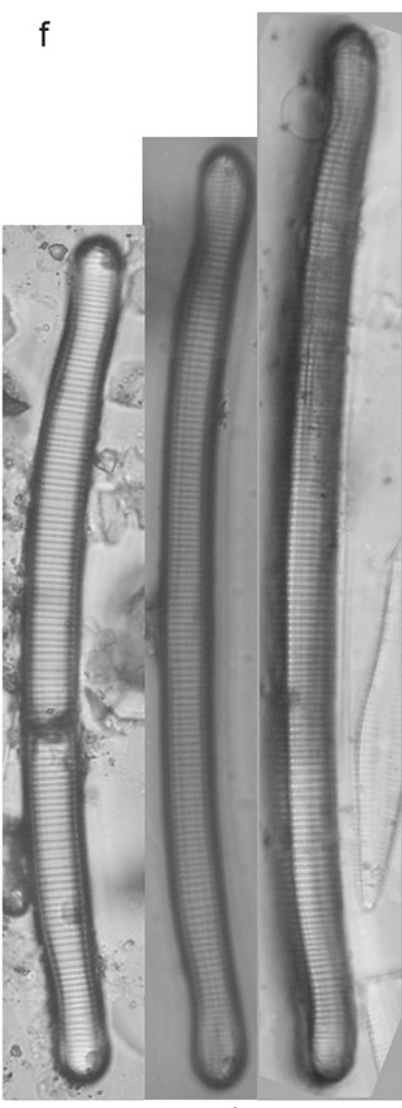

aa

$a b$

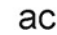

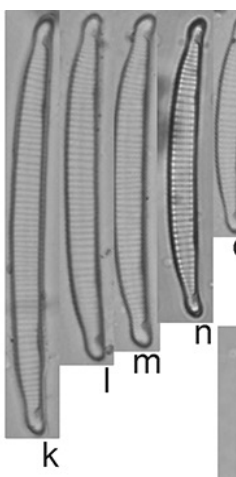

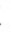

Figures 2. Eunotia of a subtropical stream adjacent to Iguaçu National Park, Brazil. LM. a-d. Eunotia ambivalens. e-j. Eunotia bilunaris. k-o. Eunotia caniculoides sp. nov. p-t. Eunotia botulitropica. u-y. Eunotia longicamelus. z. Eunotia georgii. aa-ac. Eunotia karenae. ad-ae. Eunotia desmogonioides. Scale: $10 \mu \mathrm{m}$.

Figures $2 \mathrm{k}-2 \mathrm{o}, 5 \mathrm{a}-5 \mathrm{~d}$.

Valves dorsiventral, 30.0-58.5 $\mu \mathrm{m}$ long and 3.5-4.9 $\mu \mathrm{m}$ wide. Dorsal margin slightly convex, to almost straight in the larger valves; ventral margin straight to subtly concave. Apices acutely rounded, nose-like, quite protracted from the main body, deflected to ventral side. Pseudosepta in the valve ends. Terminal nodules ventral, somewhat apart from the apices. Distal raphe ends simple, not reaching the valve center. Raphe fissure obliquely curved toward ventral mantle, with proximal ends dilated in pore. One small rimoportula per valve, at the center of the apex. Striae parallel to radiate, denser near the apices, 10-14 in 10 $\mu \mathrm{m}$ in the middle region of the valve. Areolae round, 38-40 in $10 \mu \mathrm{m}$, not visible in LM. Cingulum composed of four open bands perforated by a single linear row of pores. On the mantle, at the middle of raphe branch, 3 areolae between valve face margin and raphe fissure; 2 to 3 areolae between the raphe branch and lower mantle margin.

Holotype (here designated): BRAZIL, Paraná: São Miguel do Iguaçu, Tenente Gualberto stream, 20 september 2012, L.C. Servat (holotype UNOPA 3943!, depicted in Figure 2n.

Etymology: The epithet refers to the general similarities to Eunotia canicula Furey, Lowe \& Johansen (2011: 57, pl. 30, figs. 39-46).

Frequency of occurrence: constant (Table 3).

Taxonomic remarks: Eunotia canicula Furey, Lowe \& Johansen is similar to $E$. caniculoides, but the valve outline and ends shape are quite different. Eunotia canicula has dorsal margin more convex and higher striae density (14-15 in $10 \mu \mathrm{m})$. E. caniculoides shows longer protracted ends when compared to E. canicula (Furey et al. 2011). 


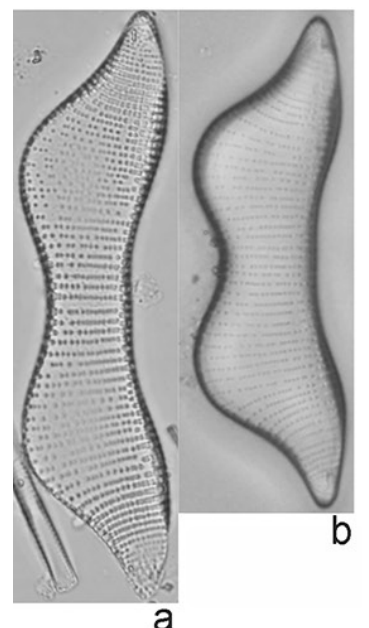

a
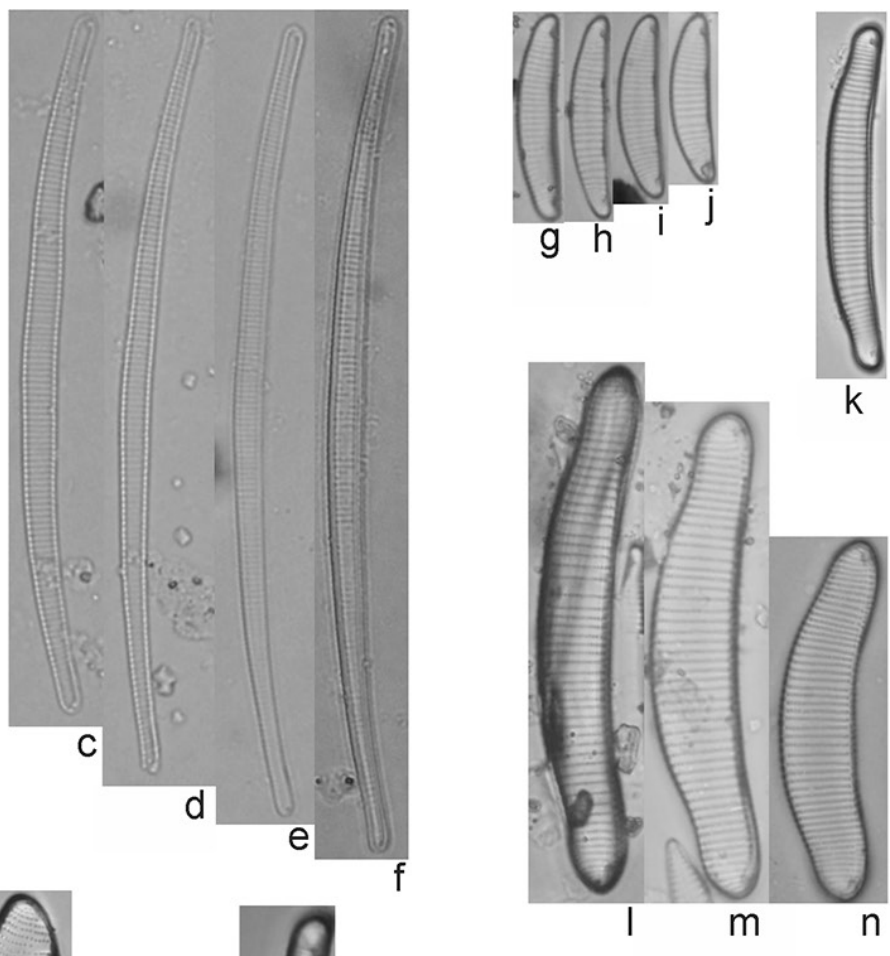
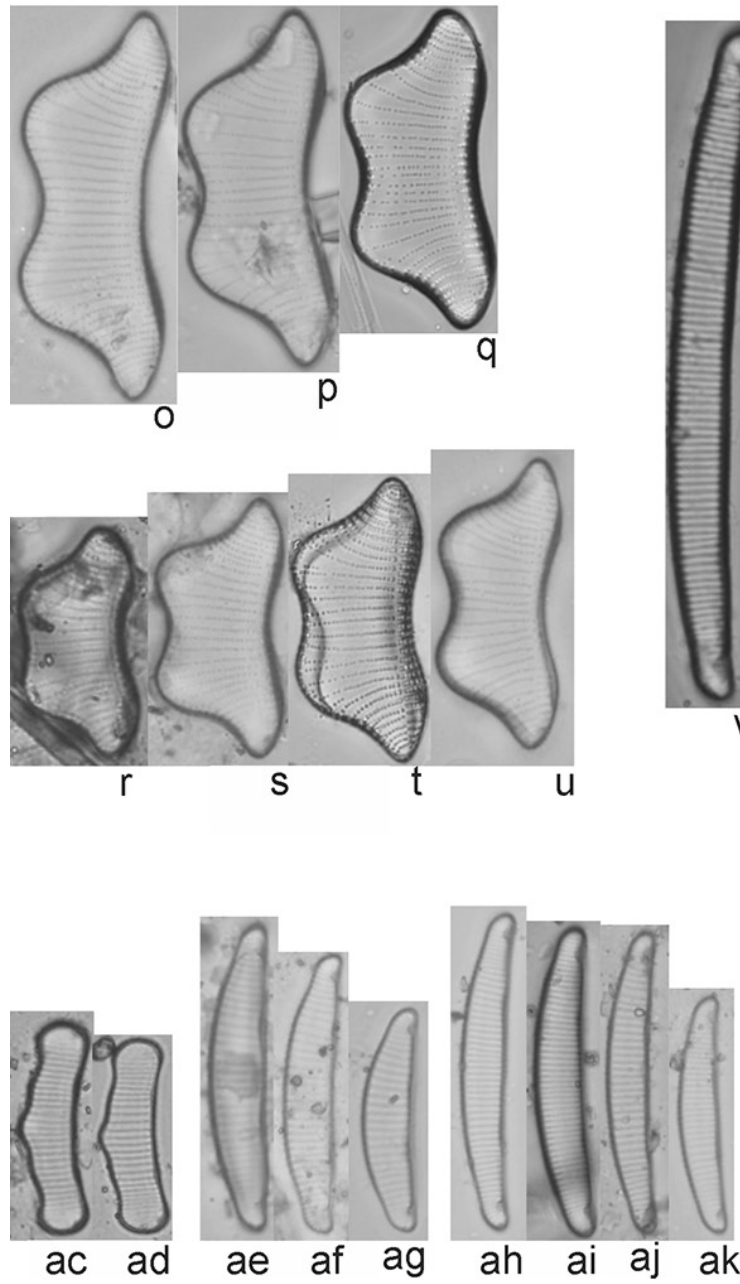

Figures 3. Eunotia of a subtropical stream adjacent to Iguaçu National Park, Brazil. LM. a-b. Eunotia guianensis. c-f. Eunotia juettnerae. g-j. Eunotia meridiana. k. Eunotia minor. 1-n. Eunotia monodon. o-u. Eunotia pileus. v-y. Eunotia pseudosudetica var. rotundata. z-ab. Eunotia rabenhorstii var. monodon. ac-ad. Eunotia rabenhorstii var. triodon. ae-ag. Eunotia pseudosudetica var. pseudosudetica. ah-ak. Eunotia sedina. al-an. Eunotia tropico-arcus. ao. Eunotia yanomami. Scale: $10 \mu \mathrm{m}$. 

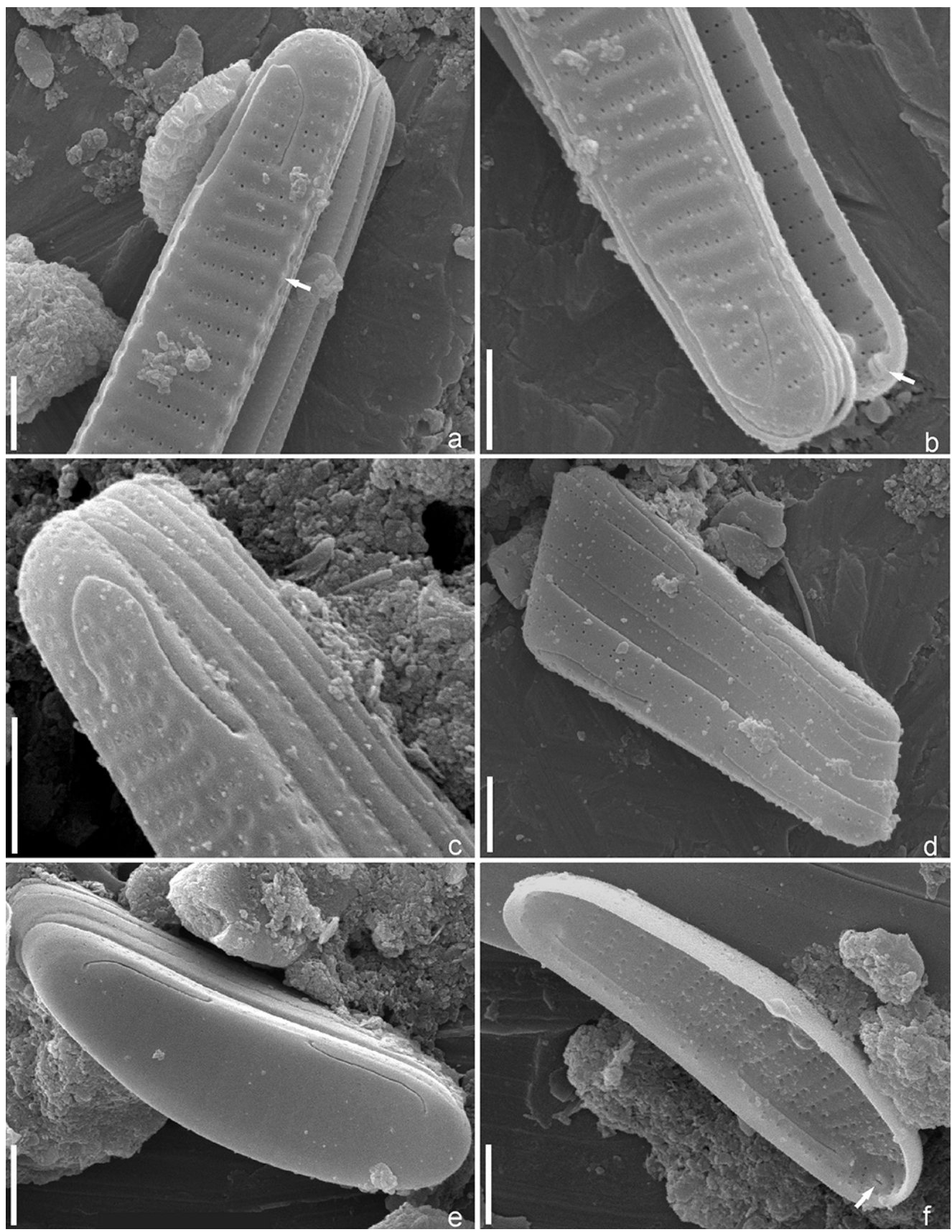

Figures 4. Eunotia of a subtropical stream adjacent to Iguaçu National Park, Brazil. SEM. a. E. ambivalens - external view of valve apex showing the raphe and striae pattern. Note the marginal spines (arrow). b. E. bilunaris - external and internal view of valve apex showing the raphe, striae pattern and rimoportula (arrow). c. E. bilunaris - tilted frustule showing the raphe and girdle bands. d. E. botulitropica - girdle view of frustule. e. E. botulitropica - external view of valve showing the raphe fissures. f. E. botulitropica - internal view of valve. Note the rimoportula (arrow). Scales: $2 \mu \mathrm{m}$.

Fontana \& Bicudo (2012) found E. canicula in the Paranapanema river watershed, state of São Paulo, but the population is clearly distinct from E. caniculoides, and the striae density are even much higher $(16-22 / 10 \mu \mathrm{m})$.

Eunotia caniculoides is similar by the valvar contour and noselike apices to E. intricans Lange-Bertalot \& Metzeltin, described from a lake in Panamá (Lange-Bertalot \& Metzeltin 2009), and to E. sioliopsis Moser, Lange-Betalot \& Metzeltin, proposed based on samples collected in New Caledonia. E. intricans has similar dimensions (length $17-48 \mu \mathrm{m}$, width $4.0-5.0 \mu \mathrm{m}$ ) and striae density (11-13 in 10 $\mu \mathrm{m})$ (Table 2) but the apices are more rounded, less protracted, and not flexed to ventral side as in E. caniculoides (Lange-Bertalot \& Metzeltin 2009). E. sioliopsis shows similar dimensions and apices shape, but striae and areolae densities are lower and dorsal margins are more convex (see Table 2). Raphe distal ends in E. sioliopsis and in E. intricans are shorter in valve face and longer in the mantle; and the terminal nodules are less proeminent (Lange-Bertalot \& Metzeltin 2009, Moser et al. 1998), when compared to E. caniculoides. Also, in 


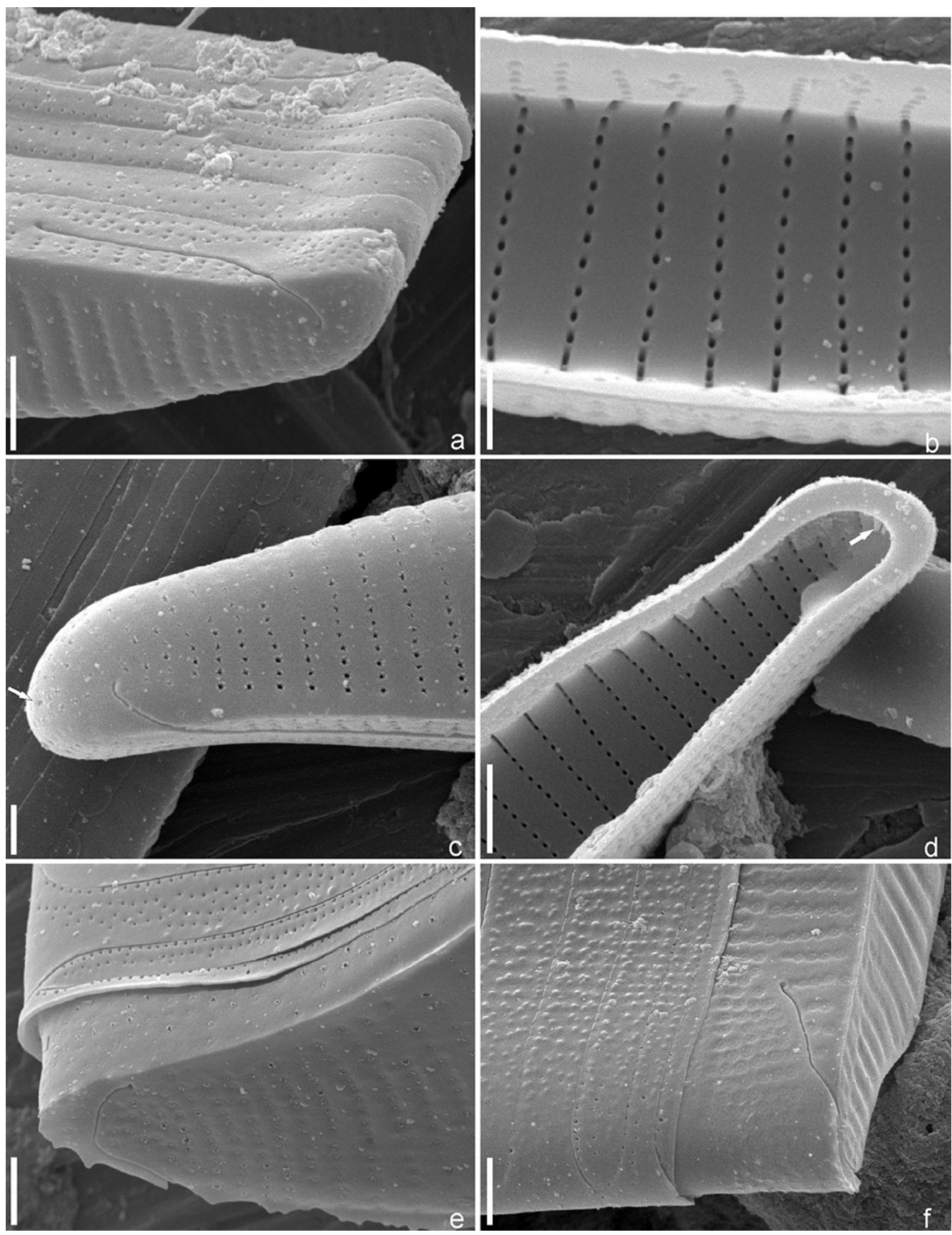

Figures 5. Eunotia of a subtropical stream adjacent to Iguaçu National Park, Brazil. SEM. a. E. caniculoides - tilted frustule showing the raphe and girdle bands. b. E. caniculoides - striae in the median region of valve in internal view. c. E. caniculoides - external view of apex. Note the rimoportula opening (arrow). d. E. caniculoides - internal view of apex showing the rimoportula (arrow). e. E. guianensis - external view of apex showing the raphe. f. E. longicamelus - girdle view of frustule showing the raphe and bands. Scales: $1 \mu \mathrm{m}$ (Figs 5b, 5c), $2 \mu \mathrm{m}$ (Figs 5a, 5d-5f).

E. sioliopsis, the areola number in the middle of the raphe branch in the mantle, between the raphe and the mantle margin is higher (4 to 5) (Moser et al. 1998), and the stability of this character in the epitheca had been reported to the genus by Mayama (2001).

Morphometric data and morphological features of closer species are compared in Table 2. Eunotia caniculoides occurred regularly along the sampling period, except in February and November.
Eunotia desmogonioides Metzeltin \& Lange-Bertalot. In: LangeBertalot, H. (ed.), Iconographia Diatomologica 11: pl. 5, figs 1-7, pl. 6: figs 1-4, 2002.

Figures 2ad-2ae, 6a-6c.

Valves linear, sometimes sinuous, $129.9-177.7 \mu \mathrm{m}$ long and 4.7-6.5 $\mu \mathrm{m}$ wide. Dorsal margin slightly convex, ventral margin almost straight. Apices capitate-rounded. Terminal nodules in the apices. Distal raphe 

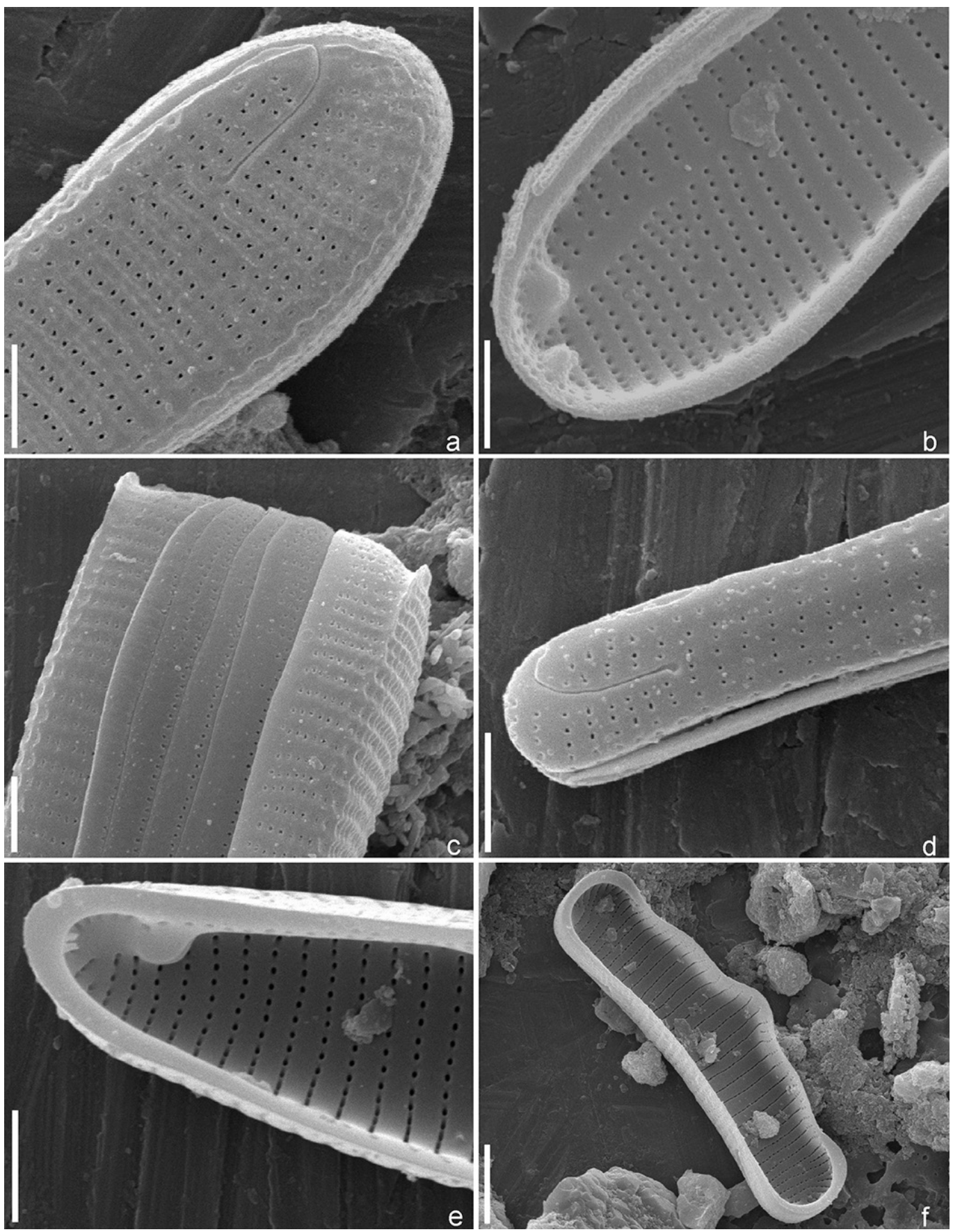

Figures 6. Eunotia of a subtropical stream adjacent to Iguaçu National Park, Brazil. SEM. a. E. desmogonioides - external view of apex showing the raphe. b. E. desmogonioides - internal view of apex showing the rinoportula and helictoglossa. c. E. desmogonioides - detail of apex of frustule showing the valvar mantle and girdle bands. d. E. juettnerae - external view of apex showing the raphe. e. E. pseudosudetica var. pseudosudetica - internal view of apex showing the rimoportula and helictoglossa. f. E. rabenhorstii var. triodon - internal view of valve. Scales: $5 \mu \mathrm{m}$ (Fig. 6f), $2 \mu \mathrm{m}$ (Figs 6a-6e).

end strongly curved onto the valve face. One rimoportula per valve, near the apex. Striae parallel, $14-15$ in $10 \mu \mathrm{m}$ in the middle region of the valve. Areolae rounded, not visible in LM. Cingulum composed of four to five open bands perforated by rows of pores.

Frequency of occurrence: common (Table 3).

Paraná State citations: Marra et al. (2016), Silva-Lehmkuhl et al. (2019); cited as Eunotia rabenhorstiana (Grunow) Hustedt): Tremarin et al. (2009)
Taxonomic remarks: Eunotia rabenhorstiana (Grunow) Hustedt resembles $E$. desmogonioides, but differs by the terminal nodules more distant from the apices, by the shorter raphe fissures in the valve face, by the presence of rimoportula at two valve poles, and marginal spines (Metzeltin \& Lange-Bertalot 1998, 2002).

Eunotia georgii Metzeltin \& Lange-Bertalot. In: Lange-Bertalot, H. (ed.), Iconographia Diatomologica 5, p. 61-62; pl. 41, fig. 1-7, pl. 42, fig. 7-8, 1998. 
Figure $2 \mathrm{z}$

Valves arched, $76.2 \mu \mathrm{m}$ long and $7.7 \mu \mathrm{m}$ wide. Dorsal margin convex with twelve undulations, ventral margin concave. Apices obtusely rounded. Terminal nodules near the apices. Striae parallel, denser near the apices, 12 in $10 \mu \mathrm{m}$ in the middle region of the valve. Rimoportula and areolae not visible in LM.

Frequency of occurrence: rare (Table 3).

Paraná State citation: first record.

Taxonomic remarks: E. georgii resembles E. muelleri Hustedt, but the latter distinguishes by the wider and more rounded ends, nodules closer to the ends and lower number of dorsal undulations. Metzeltin \& Lange-Bertalot (1998) stated that the terminal raphe fissure of $E$. muelleri extends along the valvar face reaching the dorsal margin and might be an important feature to analyse.

Eunotia guianensis (Ehrenberg) De Toni, Syll. Alg. 2: 792, 1892.

Basionym: Himantidium guianense Ehrenberg, Abh. Königl. Akad. Wiss. Berlin: 417, 2/1, fig. 4, (1841) 1843.

Figures $3 \mathrm{a}-3 \mathrm{~b}, 5 \mathrm{e}$.

Valves subtly arched, $31.5-73.1 \mu \mathrm{m}$ long and $10.2-12.7 \mu \mathrm{m}$ wide. Dorsal margin convex, with two undulations; ventral margin concave. Apices attenuate to acutely rounded, slighly deflected to the dorsal side. Terminal nodules near the apices. Distal raphe end curved onto the valve face, almost reaching the dorsal margin. Rimoportula not visible in LM. Striae parallel to radiate, not equidistant, denser near the apices, 7-12 in $10 \mu \mathrm{m}$ in the middle region of the valve. Areolae rounded, $15-18$ in $10 \mu \mathrm{m}$. Cingulum composed of six open bands perforated by several rows of pores.

Frequency of occurrence: common (Table 3).

Paraná State citation: first record.

Taxonomic remarks: the smaller valves of Eunotia guianensis resemble E. pileus Ehrenberg and E. ventriosa var. brevis (Patrick) Metzeltin \& Lange-Bertalot. E. pileus has more rounded ends and terminal raphe fissures straight. The population analyzed here is similar to Eunotia guianensis registered by Metzeltin \& Lange-Bertalot (1998:286, fig.26:1-7) in "Brasilien, Lago Calado". Registered before as part of $E$. didyma Hustedt ex Zimmermann population illustrated by Bicudo et al. (1995, fig. 24).

Eunotia juettnerae Lange-Bertalot. In: Lange-Bertalot (ed.), Diatoms of Europe 6: 127, pl. 26, figs 1-17, pl. 27, figs 1-6, 2011

Figures 3c-3f, 6d.

Valves arcuate, gradually tapering towards the apices, 51.7-121.9 $\mu \mathrm{m}$ long and 2.4-3.7 $\mu \mathrm{m}$ wide. Dorsal margin convex, ventral margin concave. Apices rounded, slightly deflected to dorsal side. Distal raphe fissure curved extending to the middle of the valve. Striae parallel, denser near the apices, 15-19 in $10 \mu \mathrm{m}$ in the middle region of the valve. Areolae rounded, ca. 50 in $10 \mu \mathrm{m}$. Rimoportula and areolae not visible in LM.

Frequency of occurrence: common (Table 3).

Paraná State citation: first record.

Taxonomic remarks: The studied population of Eunotia juettnerae has morphology and measurements (20.9-99.7 $\mu \mathrm{m}$ long, 2.5-3.1 $\mu \mathrm{m}$ wide, 17-20 striae in $10 \mu \mathrm{m}$ ) similar to those recorded in specimens from southeastern Brazil observed by Costa et al. (2017). Eunotia naegelii has narrower valves $(1.5-3.0 \mu \mathrm{m})$ and higher striae density (17-27 in $10 \mu \mathrm{m})$ and $E$. bilunaris differs on broader valves $(3.5-5.5 \mu \mathrm{m})$ and lower striae density (13-17 in $10 \mu \mathrm{m})$ (Lange-Bertalot et al. 2011).
Eunotia karenae Metzeltin \& Lange-Bertalot. In: Lange-Bertalot (ed.), Iconographia Diatomologica 18: 105, pl. 48, figs 1-4, 2007.

Figures 2aa-2ac.

Valves arched, 118.3-148.6 $\mu \mathrm{m}$ long and 6.2-7.6 $\mu \mathrm{m}$ wide. Dorsal margin convex, ventral margin concave. Apices subcapitate, slightly deflected to the dorsal side. Terminal nodules thickened, near the apices. One rimoportula per valve, near the apex. Striae parallel, denser near the apices, $10-12$ in $10 \mu \mathrm{m}$ in the middle region of the valve. Areolae visible in LM, 23-26 in $10 \mu \mathrm{m}$.

Frequency of occurrence: common (Table 3).

Paraná State citation: first record.

Taxonomic remarks: The overlapped length measure and valve contour of the neotropical E. karenae (length: 128-200 $\mu \mathrm{m}$ ) and the similar E. glacialifalsa Lange-Bertalot (length: $60-150 \mu \mathrm{m}$ ) represent a difficulty to separate both. E. glacialifalsa, a holartic species, is narrower (5-6 $\mu \mathrm{m})$, and has lower striae density $(8.5-10$ in $10 \mu \mathrm{m})$, according to (Metzeltin \& Lange-Bertalot et al. 2007). Eunotia glacialis F.Meister has wider valves $(7-12 \mu \mathrm{m})$ and E. glacispinosa Lange-Bertalot \& Cantonati possess polar spines (Lange-Bertalot 2011), characteristics that distinguish them from E. karenae.

Eunotia longicamelus L.F.Costa, D.C.Bicudo \& C.E.Wetzel, Bibliotheca Diatomologica 64: 32, pl. 73, figs 1-17, pl. 74, figs 1-8, pl. 75, figs 1-5, pl. 76, figs 1-4, 2017.

Figures $2 \mathrm{u}-2 \mathrm{y}, 5 \mathrm{f}$.

Valves arched, 22.6-73.5 $\mu \mathrm{m}$ long and 5.0-9.6 $\mu \mathrm{m}$ wide. Dorsal margin convex, with two to four undulations; ventral margin concave. Apices rostrate to subcapitate, slightly deflected to the dorsal side. Terminal nodules in the apices. Distal raphe end curved onto the valve face, reaching the dorsal margin. Striae parallel to radiate, denser near the apices, $8-15$ in $10 \mu \mathrm{m}$ in the middle region of the valve. Rimoportula and areolae not visible in LM. Cingulum composed of six open bands perforated by several rows of pores.

Frequency of occurrence: constant (Table 3).

Paraná State citations: Silva-Lehmkuhl et al. (2019); cited as E. camelus var. denticulata Grunow in Moreira-Filho \& Kutner (1962); cited as E. camelus in Tremarin et al. (2009), Bertolli et al. (2010), Faria et al. (2010), Silva et al. (2010), Santos et al. (2011), Bartozek et al. (2013), Marra et al. (2016).

Taxonomic remarks: Eunotia longicamelus is easily separated from E. camelus Ehrenberg bydorsal margin with two to four undulations and less concconcave ventral margin. Eunotia camelus has two evident undulations subdivided into two more smooth ones, and ventral margin more concave (Costa et al. 2017). The specimen shown in Figure $2 y$ slightly differs from the others (figs $2 u-2 x$ ) in the sub-capitate apices and irregular striae density pattern. Although similar to Eunotia karveerensis (Gandhi) Gluschenko \& Kulikovskiy (=E. camelus var. karveerensis Gandhi) (Glushchenko \& Kulikovskiy 2017), the valves are much more curved and narrower (6-7 $\mu \mathrm{m}$ and 4.5$5.5 \mu \mathrm{m}$ in the humps) than E. longicamelus. The authors registered a morphologically diverse population occurring in southeast Asia, western India and Ceylon.

Eunotia meridiana Metzeltin \& Lange-Bertalot. In: Lange-Bertalot (ed.), Iconographia Diatomologica 5: 67, pl. 59, figs 7-10, 1998.

Figures $3 \mathrm{~g}-3 \mathrm{j}$.

Valves subtly arched, 14.7-37.7 $\mu \mathrm{m}$ long and 3.7-5.4 $\mu \mathrm{m}$ wide. Dorsal margin convex, ventral margin linear to slightly concave. 
Apices attenuate-rounded. Terminal nodules in the ventral margins. Striae parallel to radiate, denser near the apices, $14-17$ in $10 \mu \mathrm{m}$ in the middle region of the valve. Rimoportula and areolae not visible in LM.

Frequency of occurrence: common (Table 3).

Paraná State citations: Tremarin et al. (2008, 2009), Santos et al. (2011), Marra et al. (2016).

Eunotia minor (Kützing) Grunow in Van Heurck, Syn. Diat. Belg., pl. 33: figs 20, 21, 1881.

Figure $3 \mathrm{k}$.

Valves dorsiventral, 23.5-59.0 $\mu \mathrm{m}$ long and 4.0-5.2 $\mu \mathrm{m}$ wide. Dorsal margin straight, slightly undulate; ventral margin straight to subtly concave. Apices nose-like. Terminal nodules near the apices. Striae parallel to radiate, denser near the apices, $12-17$ in $10 \mu \mathrm{m}$ in the middle region of the valve. Rimoportula and areolae not visible in LM.

Frequency of occurrence: common (Table 3).

Paraná State citations: Tremarin et al. (2009), Santos et al. (2011),Silva et al. (2010, Marra et al. 2016), Faria et al. (2019), SilvaLehmkuhl et al. (2019).

Taxonomic remarks: it is a species with complex taxonomy and we based the identification on Lange-Bertalot (2011).

Eunotia monodon Ehrenberg, Abh. K. Akad. Wiss. Berlin, p. 414, pl. 2, fig. 7, 1841 (1843).

Figures 31-3n.

Valves arched, 44.5-80.7 $\mu \mathrm{m}$ long and 7.9-10.8 $\mu \mathrm{m}$ wide. Dorsal margin convex, ventral margin concave. Apices rounded, differentiated from the main body. Terminal nodules in the apices. Striae parallel to radiate, $9-12$ in $10 \mu \mathrm{m}$ in the middle region of the valve. Rimoportula and areolae not visible in LM.

Frequency of occurrence: common (Table 3).

Paraná State citations: Tremarin et al. (2009), Marra et al. (2016); cited as E. monodon var. major (W. Smith) Hustedt - Tremarin et al. (2009), Procopiak et al. (2006), Faria et al. (2010).

Taxonomic remarks: E. maior (W. Smith) Rabenhorst is easily distinguished from E. monodon by the clearly set off capitate ends and by the more convex dorsal margin, but parallel to the ventral margin. Eunotia monodon usually has dorsal margin more strongly convex and ventral concave, but not parallel, rounded apices, slightly differentiated from the main body (Patrick \& Reimer 1966).

Eunotia pileus Ehrenberg, Ber. K. Akad. Wiss. Berlin 1841: 414 , pl. 2/1, fig. 5, 1843.

Figures $3 \mathrm{o}-3 \mathrm{u}$.

Valves subtly arched, $24.8-43.9 \mu \mathrm{m}$ long and 11.6-13.1 $\mu \mathrm{m}$ wide. Dorsal margin convex, with two undulations; ventral margin concave. Apices obtusely rounded to cuneate, weakly deflected to the dorsal side. Terminal nodules in the apices. Rimoportula not visible in LM. Striae parallel to radiate, not equidistant, denser near the apices, 7-10 in 10 $\mu \mathrm{m}$ in the middle region of the valve. Areolae rounded, 15-19 in $10 \mu \mathrm{m}$.

Frequency of occurrence: common (Table 3).

Paraná State citation: first record.

Taxonomic remarks: see Eunotia guianensis for comments.

Eunotia pseudosudetica Metzeltin, Lange-Bertalot \& GarcíaRodríguez var. pseudosudetica. In: Lange-Bertalot (ed.), Iconographia Diatomologica 15: 57, pl. 24, figs 15-18, 2005.

Figures 3ae-ag, 6e.

Valves dorsiventral, 27.2-38.0 $\mu \mathrm{m}$ long and 4.8-6.6 $\mu \mathrm{m}$ wide. Dorsal margin convex, ventral margin straight to subtly concave. Apices nose-like, differentiated from the main body. Terminal nodules near the apices. Distal raphe end short, obliquely curved onto the valve face. One rimoportula per valve, near the apex. Striae parallel to radiate, denser near the apices, $11-15$ in $10 \mu \mathrm{m}$ in the middle region of the valve. Areolae rounded, ca. 38 in $10 \mu \mathrm{m}$.

Frequency of occurrence: common (Table 3).

Paraná State citations: Bartozek et al. (2013), Tremarin et al. (2009), Marra et al. (2016), Silva-Lehmkuhl et al. (2019).

Taxonomic remarks: The population of Eunotia pseudosudetica analyzed here is similar to type material from Uruguay (Metzeltin et al. 2005) and to southern Brazilian specimens described and illustrated by Cavalcante et al. (2014).

Eunotia pseudosudetica var. rotundata Cavalcante, Tremarin \& T. Ludwig. In: Cavalcante et. al., Biota Neotropica 14(3): 10, figs 67-74, 80-83, 2014.

Figures $3 v-3 y$.

Valves dorsiventral, 52.0-63.3 $\mu \mathrm{m}$ long and 5.0-6.0 $\mu \mathrm{m}$ wide. Dorsal margin slightly convex, ventral margin subtly concave to almost straight. Apices rounded, subtly nose-like. Terminal nodules near the apices. Striae parallel to radiate, denser near the apices, 11-16 in 10 $\mu \mathrm{m}$ in the middle region of the valve. Rimoportula and areolae not visible in LM.

Frequency of occurrence: common (Table 3).

Paraná State citation: first record.

Taxonomic remarks: Eunotia pseudosudetica var. rotundata was originally found in macrophyte samples collected in the state of Santa Catarina. The more rounded ends and less pronounced dorsiventrality distinguish this variety from the typical (Cavalcante et al. 2014).

Eunotia rabenhorstii var. monodon Cleve \& Grunow. In: Van Heurck, Syn. Diat. Belg., pl. 35, fig. 12B, 1881.

Figures $3 \mathrm{z}-3 \mathrm{ab}$.

Valves arched, 17.2-32.7 $\mu \mathrm{m}$ long and 6.2-8.5 $\mu \mathrm{m}$ wide. Dorsal margin convex with one undulation in the middle of the valve, ventral margin concave. Apices broadly rounded. Terminal nodules in the apices. Striae parallel to radiate, denser near the apices, $12-15$ in 10 $\mu \mathrm{m}$ in the middle region of the valve. Rimoportula and areolae not visible in LM.

Frequency of occurrence: common (Table 3).

Paraná State citations: Tremarin et al. (2009), Marra et al. (2016), Silva-Lehmkuhl et al. (2019), Faria et al. (2010, 2019).

Taxonomic remarks: The pronounced dorsal median undulation distinguishes $E$. rabenhorstii var. monodon from $E$. rabenhorstii var. triodon characterized by three dorsal undulations (Van Heurck, 1881).

Eunotia rabenhorstii var. triodon Cleve \& Grunow. In: Van Heurck, Syn. Diat. Belg., pl. 35, fig. 12A, 1881.

Figures 3ac-3ad, $6 f$.

Valves slightly arched, 22.9-32.7 $\mu \mathrm{m}$ long and 6.5-8.5 $\mu \mathrm{m}$ wide. Dorsal margin convex with three undulations being the median undulation more pronounced than the others; ventral margin concave. Apices broadly rounded. Terminal nodules in the apices. Striae parallel to radiate, denser near the apices, $12-14$ in $10 \mu \mathrm{m}$ in the middle region of the valve. Rimoportula and areolae not visible in LM. In SEM, 40 areolae in $10 \mu \mathrm{m}$.

Frequency of occurrence: constant (Table 3).

Paraná State citations: Tremarin et al. (2009), Bartozek et al. (2013). 
Eunotia sedina Lange-Bertalot, Bak \& Witkowski. In: LangeBertalot (ed.), Diatoms of Europe 6: 215, pl. 47, figs 1-17, 2011.

Figures 3ah-3ak.

Valves dorsiventral, 22.1-40.5 $\mu \mathrm{m}$ long and 4.7-5.5 $\mu \mathrm{m}$ wide. Dorsal margin convex, ventral margin straight to slightly concave. Apices rounded, subtly nose-like, undifferentiated to the main body. Terminal nodules near the apices. Striae parallel to radiate, denser near the apices, $12-14$ in $10 \mu \mathrm{m}$ in the middle region of the valve. Rimoportula and areolae not visible in LM.

Frequency of occurrence: common (Table 3).

Paraná State citation: first record.

Taxonomic remarks: the analyzed population was similar to that described by Lange-Bertalot et al. (2011). E. sedina resembles Eunotia sioliopsis Moser, Lange-Bertalot \& Metzeltin, but the later differs by narrower valves (length $20-40 \mu \mathrm{m}$, width 3.5-4.5 $\mu \mathrm{m}$ ) and higher striae density (16-17 in $10 \mu \mathrm{m})$ (Moser et al. 1998).

Eunotia tropico-arcus Metzeltin \& Lange-Bertalot. In: LangeBertalot (ed.), Iconographia Diatomologica 18: 123, pl. 74, figs 1-10, 2007.

Figures 3al-3an.

Valves dorsiventral, 34.3-56.1 $\mu \mathrm{m}$ long and 7.6-8.5 $\mu \mathrm{m}$ wide. Dorsal margin convex with a median depression; ventral margin slightly concave. Apices truncate, differentiated to the main body. Terminal nodules in the apices. Striae parallel to radiate, denser near the apices, $11-12$ in $10 \mu \mathrm{m}$ in the middle region of the valve. Rimoportula and areolae not visible in LM.

Frequency of occurrence: sporadic.

Paraná State citation: first record.

Taxonomic remarks: Eunotia tropico-arcus resembles E. bidens Ehrenberg, E. praerupta Ehrenberg and E. arcus Ehrenberg. However, E. bidens has more pronounced dorsal median depression and E. praerupta has dorsal margin strongly convex and higher valve width $(10-18 \mu \mathrm{m})$ (Metzeltin \& Lange-Bertalot 2007, Lange-Bertalot et al. 2011). Finally, E. arcus differs in having more arched valves, concave ventral margin and wider apices (Metzeltin \& Lange-Bertalot 2007).

Eunotia yanomami Metzeltin \& Lange-Bertalot. In: Lange-Bertalot (ed.), Iconographia Diatomologica 5: 86, pl. 34, figs 1-6, pl. 35, figs 1-6, pl. 36, figs 1-13, pl. 37, figs 7-8, 1998.

Figure 3ao.

Valves arched, 67.0-95.3 $\mu \mathrm{m}$ long and 10.8-13.2 $\mu \mathrm{m}$ wide. Dorsal margin convex with two undulations; ventral margin concave. Apices cuneate, rounded. Terminal nodules near the apices. Striae parallel to radiate, denser near the apices, 15-16 in $10 \mu \mathrm{m}$ in the middle region of the valve. Rimoportula and areolae not visible in LM.

Frequency of occurrence: sporadic (Table 3).

Paraná State citations: Marra et al. (2016), Silva-Lehmkuhl et al. (2019); cited as Eunotia zygodon Ehrenberg in Tremarin et al. (2008).

Taxonomic remarks: Metzeltin \& Lange-Bertalot (1998) described E. yanomami based on Brazilian samples. This species resembles $E$. zygodon Ehrenberg, however, E. zygodon has a trilobate terminal nodule (Patrick \& Reimer 1966) and smaller valves (lectotype: length $53.3 \mu \mathrm{m}$ and width $10 \mu \mathrm{m})$ (Reichardt 1995). Ferrari et al. (2007) commented that further studies would be needed in order to conclude on the best distinguishing features between the two species.

The more common taxa in the studied river, occurring in at least $50 \%$ of the samples, were: E. bilunaris, E. ambivalens, E. longicamelus,
E. karenae, E. minor, E. pseudosudetica var. rotundata, E. monodon, E. juettnerae, E. pileus, E. rabenhorstii var. monodon, E. rabenhorstii var. triodon, E. botulitropica and E. sedina. $66.6 \%$ of identified species were widely distributed in the study area and considered of common occurrence, $19.04 \%$ were constant, $9.52 \%$ were sporadic and $4.76 \%$ were rare. In general, the high frequencies of occurrence of the periphytic Eunotia community were in the spring period (76\%) and in October (71\%).

\section{Discussion}

The number of taxa found in the present study (21) can be considered high when compared to Eunotia studies carried out in other Brazilian regions that used a similar methodology, obtaining samples by squeezing an aquatic macrophyte. We highlight Ludwig \& Valente-Moreira (1989) that identified 24 Eunotia and Santos et al. (2011) with 18 species. Other studies about diatom flora based on samples collected in the state of Paraná included 44 taxa (Tremarin et al. 2008), 16 taxa (Marra et al. 2016), 13 taxa (Bichoff et al. 2016), 10 taxa (Fürstenberger \& ValenteMoreira 2000), and 8 taxa (Bertolli et al. 2010). Bicudo et al. (1995) identified 14 taxa on samples from Mato Grosso wetland, Cavalcante et al. (2014) found 12 taxa in the state of Santa Catarina, and Ferrari et al. (2007) registered 23 species in amazonian water bodies.

Despite numerous investigations of diatom diversity in the state of Paraná, the taxonomic study of the Eunotia based on 12 samples from the Tenente João Gualberto stream resulted in eight new citations for the State, and Eunotia caniculoides was proposed as new. The more common taxa in the studied river, occurring in at least $50 \%$ of the samples, were: E. bilunaris, E. ambivalens, E. longicamelus, E. karenae, E. pseudosudetica var. rotundata, E. monodon, E. juettnerae, E. pileus, E. rabenhorstii var. monodon, E. rabenhorstii var. triodon, E. botulitropica and E. sedina. $66.6 \%$ of identified species were widely distributed in the study area and considered of common occurrence, $19.04 \%$ were constant, $9.52 \%$ were sporadic and $4.76 \%$ were rare. In general, the high frequencies of occurrence of the periphytic Eunotia community were in the spring period (76\%) and in October $(71 \%)$.

Species of Eunotiaceae are influenced by $\mathrm{pH}$ and prefer acidic water (Patrick \& Reimer 1966, Cantonati \& Lange-Bertalot 2011). They are typical components of the diatom flora from tropical and subtropical areas, frequently associated with acid waters and oligotrophic or dystrophic habitats (Metzeltin \& Lange Bertalot 1998, Kociolek \& Spaulding 2003, Furey et al. 2011, Burliga et al. 2013). During this study period, the annual $\mathrm{pH}$ mean value was predominantly acidic (6.3), an environmental condition that may have favored the species richness of Eunotia. The months of September and October 2012, April and June 2013, with greater richness of Eunotia taxa, showed higher concentrations of dissolved oxygen (11.05 - $\left.22.89 \mathrm{mg} . \mathrm{L}^{-1}\right)$. Of the months cited, those of 2012 had higher concentrations of TP and $\mathrm{NO}_{3}$ (0.0198-0.0523 mg.L $\mathrm{L}^{-1}$ and 0.365-0.3775 mg. $\mathrm{L}^{-1}$ respectively), and lower depth and flow values $\left(0.16-0.21 \mathrm{~m}\right.$ and $0.16-0.20 \mathrm{~m}^{3} \cdot \mathrm{s}^{-1}$ respectively).

In conclusion, Eunotia is of great taxonomic complexity and studies are still needed, leading to more complete knowledge of species diversity and distribution in Brazil. In addition, taxonomic knowledge of Eunotia species is essential due to their already known ecological preferences, being useful information for ecological researches aimed at the conservation and management of aquatic environments. 


\section{Acknowledgments}

The authors acknowledge Coordenação de Aperfeiçoamento Pessoal de Nível Superior (CAPES) for master scholarship to CCRF and PhD scholarship to GM and PIT. Conselho Nacional de Desenvolvimento Científico e Tecnológico $(\mathrm{CNPq})$ is thanked for the productivity grant to TAVL (311876/2019-6). We are also grateful to the Centro de Microscopia Eletrônica of Universidade Federal do Paraná for the availability of the scanning electron microscope, and to the Gerpel (Grupo de Pesquisa em Recursos Pesqueiros e Limnologia) by the chemical analyzes of water. Paula C. Ferreira is acknowledged for helping with plates edition and taxa discussion. We thank the reviewers for their careful reading of this manuscript, which significantly improved the text.

\section{Author Contributions}

Norma Bueno: contributed in the concept and design of the study. Cinthia Favaretto: contributed in the data collections.

Cinthia Favaretto, Priscila Tremarin, Thelma Ludwig, Gabriela Medeiros, Norma Bueno: contributed to data analysis and interpretation; critical revision and manuscript preparation, all adding intellectual content.

\section{Conflicts of Interest}

The authors declare that they have no conflict of interest related to the publication of this manuscript.

\section{References}

ALVARES, C.A., STAPE, J.L., SENTELHAS, P.C., GONÇALVES, J.L.M. \& SPAROVEK, G. 2013. Köppen's climate classification map for Brazil. Meteor. Zeitsch. 22: 711-728.

AMERICAN PUBLIC HEALTH ASSOCIATION. 2005. Standard Methods for Examination of Water and Wastewater. APHA, Washington.

BARBER, H.G. \& HAWORTH, E.Y. 1981. A guide to the morphology of the diatom frustule. Fresh. Biol. Assoc. 44: 1-112.

BARTOZEK, E.C.R., BUENO, N.C., LUDWIG, T.A.V., TREMARIN, P.I., NARDELLI, M.S. \& ROCHA, A.C.R. 2013. Diatoms (Bacillariophyceae) of Iguaçu National Park, Foz do Iguaçu, Brazil. Acta Bot. Bras. 27(1): 108123. http://dx.doi.org/10.1590/S0102-33062013000100012.

BARTOZEK, E.C.R., TREMARIN, P.I., PERES, C.K. \& BRANCO, C.C.Z. 2020. Eunotia itacueretabaensis sp. nov. (Bacillariophyceae, Eunotiaceae) from the Campos Gerais region, Southern Brazil. Phytotaxa 439(1): 067076. https://doi.org/10.11646/phytotaxa.439.1.4.

BERTOLLI, L.M., TREMARIN, P.I. \& LUDWIG, T.A.V. 2010. Diatomáceas perifíticas em Polygonum hydropiperoides Michaux, reservatório do Passaúna, Região Metropolitana de Curitiba, Paraná, Brasil. Acta Bot. Bras. 24: 1065-1081. https://doi.org/10.1590/S0102-33062010000400022

BICCA, A.B., TORGAN, L.C. \& SANTOS, C.B. 2011. Eunotiaceae (Eunotiales, Bacillariophyta) em ambientes lacustres na Planície Costeira do Sul do Brasil. Rev. Bras. Bot. 34: 1-19. https://doi.org/10.1590/S010084042011000100002

BICHOFF, A., OSORIO, N.C., DUNCK, B. \& RODRIGUES, L. (2016). Periphytic algae in a floodplain lake and river under low water conditions. Biota Neotrop. 16(3): e20160159. http://dx.doi.org/10.1590/1676-0611BN-2016-0159

BICUDO, C.E.M. \& MENEZES, M. 2017. Gêneros de algas de águas continentais do Brasil. RiMa, São Carlos.

BICUDO, D.C., DE-LAMONICA-FREIRE, E., FIGUEIREDO, D.M. \& LIMA, D. 1995. Ficoflórula do pantanal de Mato Grosso, Brasil: Centrales e Eunotiaceae (Bacillariophyceae). Hoehnea 22(1/2): 165-182.
BURLIGA, A.L., KOCIOLEK, J.P., SALOMONI, S.E. \& FIGUEREDO, D. 2013. A new genus and species in the diatom family Eunotiaceae Kützing (Bacillariophyceae) from the Amazonian hydrographic region, Brazil. Phytotaxa 79(2): 47-57. https://doi.org/10.11646/phytotaxa.79.2.1

CANANI, L.G. \& TORGAN, L.C. 2013. Two new Eunotia species with subapical costae, an uncommon structure for the genus. Diatom Res. 28(4): 395-406. https://doi.org/10.1080/0269249X.2013.821425.

CANTONATI, M. \& LANGE-BERTALOT, H. 2011. Diatom monitors of closeto-pristine, very-low alkalinity habitats: three new Eunotia species from springs in Nature Parks of the south-eastern Alps. J. Limnol. 70: 209-221. https://doi.org/10.4081/jlimnol.2011.209.

CAVALCANTE, K.P., TREMARIN, P.I., CASTRO, E.C., TIBIRIÇÁ, C.E.J.A., WOJCIECHOWSKI, J. \& LUDWIG, T.A.V. 2014. Epiphytic Eunotia (Bacillariophyceae) on Podostemum from Santa Catarina, southern Brazil, including new observations on morphology and taxonomy of some rare recorded species. Biota Neotrop. 14(3): 1-12. https://doi.org/10.1590/167606032014003414.

COSTA, L.F., WETZEL, C.E., LANGE-BERTALOT, H., ECTOR, L. \& BICUDO, D.C. 2017. Taxonomy and ecology of Eunotia species (Bacillariophyta) in southeastern Brazilian reservoirs. Bibl. Diatomol. 64: 1-302.

COX, E. 2015. Coscinodiscophyceae, Mediophyceae, Fragilariophyceae, Bacillariophyceae (Diatoms). In: Frey, W. (Ed.). Syllabus of plant families. A. Engler Syllabus der Pflantzenfamilien. 2/1 Photoautotrophic eukaryotic algae. Borntraeger, Stuttgart, p. 64-103.

DAJOZ, R. 2005. Princípios de Ecologia. Artmed, Porto Alegre.

DUNCK, B., NOGUEIRA, I.S. \& FELISBERTO, S.A. 2013a. Distribution of periphytic Algae in wetlands (Palm swamps, Cerrado), Brazil. Braz. J. Biol. 73: 331-346. https://doi.org/10.1590/S1519-69842013000200013

DUNCK, B., NOGUEIRA, I.S. \& FELISBERTO, S.A. 2013b. Composição e diversidade de algas perifíticas em veredas sob diferentes impactos antrópicos (Goiás, Brasil). Iheringia. Sér. Bot. 68: 237-248.

DUNCK, B., RUWER, D.T. \& FELISBERTO, S.F. (2016) Eunotiaceae Kützing (Bacillariophyceae) perifíticas de áreas úmidas do Cerrado (veredas) no Brasil. Iheringia, sér. Bot. 71(3): 283-295.

EHERENBERG, C.G. 1843. Verbreitung und Einfluss des mikroskopischen Lebens in Süd- und Nordamerika. Physikalische Abhandlungen der Königlichen Akademie der Wissenschaften zu Berlin 1841: 291-445.

FARIA, D.M., TREMARIN, P.I. \& LUDWIG, T.A.V. 2010. Diatomáceas perifíticas da represa Itaqui, São José dos Pinhais, Paraná: Fragilariales, Eunotiales, Achnanthales e Gomphonema Ehrenberg. Biota Neotrop. (10)3: 415-527. http://dx.doi.org/10.1590/S1676-06032010000300035.

FARIA, D.M., COSTIN, J.C.,TREMARIN, P.I. \& LUDWIG, T.A.V. 2019. Temporal changes in biological traits of diatom communities in response to an oil spill in a subtropical river. An. Acad. Bras Ciec. 91(2): e20170863. http://dx.doi.org/10.1590/0001-3765201920170863.

FAUSTINO, S.B., FONTANA, L., BARTOZEK, E.C.R., BICUDO, C.E.M., BICUDO, D.C. 2016. Composition and distribution of diatom assemblages from core and surface sediments of a water supply reservoir in Southeastern Brazil. Biota Neotropica 16(2): e20150129. https://doi.org/10.1590/1676-0611-BN-2015-0129.

FERRARI, F., PROCOPIAK, L.K., ALENCAR, Y.B. \& LUDWIG, T.A.V. 2007. Eunotiaceae (Bacillariophyceae) em igarapés da Amazônia Central, Manaus e Presidente Figueiredo, Brasil. Acta Amaz. 37:1-16. http://dx.doi. org/10.1590/S0044-59672007000100001

FONTANA, L. \& BICUDO, D.C. 2012. Biodiversidade e distribuição das diatomáceas (Bacillariophyceae) de sedimentos superficiais nos reservatórios em cascata do rio Paranapanema (SP/PR, Brasil). Hoehnea 39: 587-612.

FUREY, P. 2011. Eunotia rhomboidea. Diatoms of the United States. Retrieved March 21, 2017, from http://westerndiatoms.colorado.edu/taxa/species/ eunotia_rhomboidea.

FUREY, P.C, LOWE, R.L. \& JOHANSEN, R.J. 2011. Eunotia Ehrenberg (Bacillariophyta) of the Great Smoky Mountains National Park, USA. Biblioth. Diatomol. 56:1-133.

FÜRSTENBERGER, C. \& VALENTE-MOREIRA, I.M. 2000. Diatomáceas (Bacillariophyta) perifíticas da lagoa Tarumã, Ponta Grossa, Paraná, Brasil. Insula 29: 117-134. 
GLUSHCHENKO, A.M. \& KULIKOVSKIY, M.S. 2017. Taxonomy and distribution of Eunotia camelus (Eunotiaceae, Bacillariophyceae) infraspecific taxa from waterbodies of South-East Asia. Botanicheskii Zhurnal. 102: 329-338.

HORTON, R.E. 1945. Erosional development of streams and their drainage basins: hydrophysical approach to quantitative morphology. Geol. Soc. Am. Bull. 56: 275-370.

HUSTEDT, F. 1949. Süsswasser-Diatomeen aus dem Albert Nationalpark in Belgisch- Kongo. Exploration du Parc National Albert; Mission H. Damas (1935-1936), Fasc. 8: 199 pp.

HUSTEDT, F. 1950. Die Diatomeenflora norddeutscher Seen mit besonderer Berücksichtigung des holsteinischen Seengebiets. V-VII. Seen in Mecklenburg, Lauenburg und Nordostdeutschland. Archiv für Hydrob. 43: 329-458, pls XXI-XLI

HUSTEDT, F. 1952a. Neue und wenig bekannte Diatomeen. III. Phylogenetische Variationen bei den raphidioiden Diatomeen. Ber. Deutsch. Bot. Ges. 65: 133-145.

HUSTEDT, F. 1952b. Neue und wenig bekannte Diatomeen. IV. Botaniska Notiser, Hafte 4: 366-410.

HUSTEDT, F. 1965. Neue und wenig bekannte Diatomeen. IX. Süßwasser diatomeen aus Brasilien, insbesondere des Amazonas gebietes. Int. Rev. Hydrobiol. 50: 391-410.

KOCIOLEK, J.P. \& SPAULDING, S. 2003. Eunotioid and asymmetrical naviculoid diatoms. In Freshwater Algae of North America. Ecology and classification. (J.D. Wehr \& R.G.F. Sheath, eds). London, Academic Press Elsevier Science.

KRAMMER, K. \& LANGE-BERTALOT, H. 1991. Bacillariophyceae. 3 Teil: Centrales, Fragilariaceae, Eunotiaceae. In Süsswasser-Flora von Mitteleuropa 2/3 (H. Ettl, J. Gerloff, H. Heynig \& D. Mollenhauer, eds). Gustav Fischer Verlag, Stuttgart, Jena, pp. 1-576.

LANGE-BERTALOT, H. \& METZELTIN, D. 2009. A dystrophic mountain lake in Panamá - hot spot of new and rare neotropical diatoms. Beihefte Nova Hedwigia 135: 137-165.

LANGE-BERTALOT, H., BAK, M., WITKOWSKI, A. \& TAGLIAVENTI, N 2011. Eunotia and some related genera. In Diatoms of Europe (H. LangeBertalot ed). Gantner Verlag K.G., Ruggell, 747 p.

LUDWIG, T.A.L. \& VALENTE-MOREIRA, I.M. 1989. Contribuição ao conhecimento da diatomoflórula do parque regional do Iguaçu, Curitiba, Paraná, Brasil: I. Eunotiaceae (Bacillariophyceae). Arq. Biol. Tecnol. 32: 543-560.

MARRA, R.C., TREMARIN, P.I., ALGARTE, V.M. \& LUDWIG, T.A.V. 2016. Epiphytic diatoms (Diatomeae) from Piraquara II urban reservoir, Paraná state. Biota Neotrop. 16(4) e20160200. http://dx.doi.org/10.1590/16760611-BN-2016-0200.

MAYAMA, S. 2001. Valuable taxonomic characters in the valve mantle and girdle of some Eunotia species. In Lange-Bertalot-Festschrift: Studies on Diatoms (R. Jahn, J.P. Kociolek, A. Witkowski \& P. Compère, eds.) Gantner Verlag K.G., Ruggell, p. 119-130.

METZELTIN, D. \& LANGE-BERTALOT, H. 1998. Tropical Diatoms of South America I. About 700 predominantly rarely known or new taxa representative of the neotropical flora. In Iconographia Diatomologica, Annotated Diatom Monographs. (H. Lange-Bertalot, ed.) Gantner Verlag K.G., Ruggell, 5: 1-220.

METZELTIN, D. \& LANGE-BERTALOT, H. 2002. Diatoms from the Island Continent Madagascar. In Iconographia Diatomologica, Annotated Diatom Monographs. (H. Lange-Bertalot, ed.). Gantner Verlag K.G., Ruggell, 11: 1-286.

METZELTIN, D., LANGE-BERTALOT, H. \& GARCÍA-RODRÍGUEZ, F. 2005. Diatoms of Uruguay compared with other taxa from South America and elsewhere. In Iconographia Diatomologica, Annotated Diatom Monographs. (H. Lange-Bertalot, ed.). Gantner Verlag K.G., Ruggell, 15: 1-736.

METZELTIN, D. \& LANGE-BERTALOT, H. 2007. Tropical Diatoms of south America II. Special remarks on biogeographic disjunction. In Iconographia Diatomologica, Annotated Diatom Monographs.(H. Lange-Bertalot, ed.) Gantner Verlag K.G., Ruggell, 18: 1-1876.
MOREIRA-FILHO, H. \& KUTNER, M.B. 1962. Contribuição para o estudo das diatomáceas do manguezal de Alexandra, Estado do Paraná. Bol. Univ. Fed. Paraná 4: 1-36.

MOREIRA-FILHO, H. \& VALENTE-MOREIRA, I.M. 1981. Avaliação taxonômica e ecológica das diatomáceas (Bacillariophyceae) epífitas em algas pluricelulares obtidas nos litorais dos Estados do Paraná, Santa Catarina e São Paulo. Bol. Mus. Bot. Mun. 47: 1-17.

MORO, R.S. \& FURSTENBERGER, C.B. 1997. Catálogo dos principais parâmetros ecológicos de diatomáceas não-marinhas. Editora UEPG, Ponta Grossa.

MOSER, G., LANGE-BERTALOT, H. \& METZELTIN, D. 1998. Insel der Endemiten. Geobotanisches Phänomen Neukaledonien. Island of endemics New Caledonia - a geobotanical phenomenon. Bibl. Diatomol 38:[1]-464, 101 pls.

NOVITSKI, L. \& KOCIOLEK, P. 2005. Preliminary light and scanning electron microscope observations of marine fossil Eunotia species with remarks on the evolution of the genus. Diatom Res. 20(1): 137-143. https://doi.org/10 .1080/0269249X.2005.9705623.

PATRICK, R. 1940a. Some new diatoms from Brazil. Not. Nat. 59: 1-7.

PATRICK, R. 1940b. Some nomenclatural problems and a new species and a new variety in the genus Eunotia (Bacillariophyceae). Not. Nat. 312: 1-15.

PATRICK, R. \& REIMER, C.W. 1966. The diatoms of the United States: exclusive of Alaska and Hawai.1. Monographs 13. Philadelphia: Academy of Natural Sciences.

PROCOPIAK, L.K., FERNANDES, L.F. \& MOREIRA-FILHO, H. 2006. Diatomáceas (Bacillariophyta) marinhas e estuarinas do Paraná, Sul do Brasil: lista de espécies com ênfase em espécies nocivas. Biota Neotrop. 6(3) http://www.biotaneotropica.org.br/v6n3/pt/abstract?inventory+ bn02306032006

RABENHORST, L. 1864. Flora europaea algarum aquae dulcis et submarinae. Sectio I. Algas diatomaceas complectens, cum figuris generum omnium xylographice impressis. pp. 1-359. Lipsiae [Leipzig]: Apud Eduardum Kummerum

REICHARDT, E. 1995. Die Diatomeen (Bacillariophyceae) in Ehrenbergs Material von Cayenne, Guayana Gallica (1843). In Iconographia Diatomologica, Annotated Diatom Monographs. (H. Lange-Bertalot, ed.) Gantner Verlag K.G., Ruggell, 1: 1-49.

ROUND, F.E., CRAWFORD, R.M. \& MANN, D.G. 1990. The Diatom: biology and morphology of the genera. Cambridge University Press.

SALA, S.E., DUQUE, S.R., NUÑEZ-AVELLANEDA, M. \& LAMARO, A.A. 2002a. Diatoms from the Colombian Amazon: some species of the genus Eunotia (Bacillariophyceae). Acta Amazon. 32: 589-603. https://doi org/10.1590/1809-43922002324603.

SALA, S.E., DUQUE S.R., NUÑEZ-AVELLANEDA, M. \& LAMARO, A.A. 2002b. Diatoms from the Colombian Amazonia. Cryptogam. Algol. 23: 75-99.

SANTOS, E.M., TREMARIN, P.I. \& LUDWIG, T.A.V. 2011. Diatomáceas perifíticas em Potamogeton polygonus Cham. \& Schltdl.: citações pioneiras para o estado do Paraná. Biota Neotrop. 11(3): 303-315. http://dx.doi. org/10.1590/S1676-06032011000300025

SILVA, A.M., LUDWIG, T.A.V., TREMARIN, P.I. \& VERCELINO, I.S. 2010. Diatomáceas perifíticas em um sistema eutrófico brasileiro (Reservatório do Iraí, estado do Paraná). Acta Bot. Bras. 24(4): 997-1016. https://doi. org/10.1590/S0102-33062010000400015.

SILVA-LEHMKUHL, A.M., TREMARIN, P.I., VERCELINO, I.S. \& LUDWIG, T.A.V. 2019. Periphytic diatoms from na oligotrophic lentic system, Piraquara I reservoir, Paraná state, Brazil. Biota Neotrop. 19(2): e20180568. https://doi.org/10.1590/1676-0611-bn-2018-0568.

SIMONSEN, R. 1974. The diatom plankton of Indian Ocean Expedition of RV “Meteor" Meteor 1964-1965. Meteor Forschungsergebnisse, Reihe D: Biologie 19: 1-107.

STRAHLER, A.N. 1952. Hypsometric (area-altitude) analysis of erosional topology. Geol. Soc. Am. Bull. 63: 1117-1142.

TAVARES, B. \& VALENTE-MOREIRA, I.M. 2000. Diatomoflórula do lago de Cascavel, município de Cascavel, estado do Paraná, Brasil. Hoehnea 27(1): 1-24. 
TREMARIN, P.I., LUDWIG, T.A.V. \& MOREIRA-FILHO, H. 2008. Eunotia Ehrenberg (Bacillariophyceae) do rio Guaraguaçu, litoral do Paraná, Brasil. Acta Bot. Bras. 22: 845-867. https://doi.org/10.1590/S0102-33062008000300020

TREMARIN, P.I., FREIRE, E.G., BERTOLLI, L.M. \& LUDWIG, T.A.V. 2009. Catálogo das diatomáceas (Ochrophyta - Diatomeae) continentais do estado do Paraná. Iheringia. Sér. Bot. 64: 79-107.

VAN DAM, H., MERTENS, A. \& SINKELDAM, J. 1994. A coded checklist and ecological indicator values of freshwater diatoms from the Netherlands. Netherlands J. Aquat. Ecol. 28: 117-133.
VAN HEURCK, H. 1881. Synopsis des Diatomées de Belgique. Atlas. Anvers: Ducaju et Cie. pls 31-77.

Received: 03/06/2019

Revised: 26/11/2020

Accepted: 26/11/2020

Published online: 03/02/2021 